\title{
Growth of sulphuric acid nanoparticles under wet and dry conditions
}

\author{
L. Skrabalova ${ }^{1,2}$, D. Brus ${ }^{1,3}$, T. Anttila ${ }^{3, *}$, V. Zdimal ${ }^{1}$, and H. Lihavainen ${ }^{3}$ \\ ${ }^{1}$ Laboratory of Aerosols Chemistry and Physics, Institute of Chemical Process Fundamentals, Academy of Sciences of the \\ Czech Republic, Rozvojová 135, 16502 Prague 6, Czech Republic \\ ${ }^{2}$ Department of Physical Chemistry, Faculty of Science, Charles University in Prague, Hlavova 8, \\ Prague, 128 43, Czech Republic \\ ${ }^{3}$ Finnish Meteorological Institute, Erik Palménin aukio 1, P.O. Box 503, 00100 Helsinki, Finland \\ *now at: Tampere University of Technology, Department of Physics, P.O. Box 527, 33101 Tampere, Finland
}

Correspondence to: L. Skrabalova (skrabalova@icpf.cas.cz)

Received: 31 July 2013 - Published in Atmos. Chem. Phys. Discuss.: 12 September 2013

Revised: 20 February 2014 - Accepted: 27 April 2014 - Published: 27 June 2014

\begin{abstract}
New particle formation, which greatly influences the number concentrations and size distributions of an atmospheric aerosol, is often followed by a rapid growth of freshly formed particles. The initial growth of newly formed aerosol is the crucial process determining the fraction of nucleated particles growing to cloud condensation nuclei sizes, which have a significant influence on climate. In this study, we report the laboratory observations of the growth of nanoparticles produced by nucleation of $\mathrm{H}_{2} \mathrm{SO}_{4}$ and water in a laminar flow tube at temperatures of 283, 293 and $303 \mathrm{~K}$, under dry (a relative humidity of $1 \%$ ) and wet conditions (relative humidity of $30 \%$ ) and residence times of 30, 45, 60 and $90 \mathrm{~s}$. The initial $\mathrm{H}_{2} \mathrm{SO}_{4}$ concentration spans the range from $2 \times 10^{8}$ to $1.4 \times 10^{10}$ molecule $\mathrm{cm}^{-3}$ and the calculated wall losses of $\mathrm{H}_{2} \mathrm{SO}_{4}$ were assumed to be diffusion limited. The detected particle number concentrations, measured by the Ultrafine Condensation Particle Counter (UCPC) and Differential Mobility Particle Sizer (DMPS), were found to depend strongly on the residence time. Hygroscopic particle growth, presented by growth factors, was found to be in good agreement with the previously reported studies. The experimental growth rates ranged from $20 \mathrm{~nm} \mathrm{~h}^{-1}$ to $890 \mathrm{~nm} \mathrm{~h}^{-1}$ at relative humidity (RH) $1 \%$ and from $7 \mathrm{~nm} \mathrm{~h}^{-1}$ to $980 \mathrm{~nm} \mathrm{~h}^{-1}$ at $\mathrm{RH}$ $30 \%$ and were found to increase significantly with the increasing concentration of $\mathrm{H}_{2} \mathrm{SO}_{4}$. Increases in the nucleation temperature had a slight enhancing effect on the growth rates under dry conditions. The influence of relative humidity on growth was not consistent - at lower $\mathrm{H}_{2} \mathrm{SO}_{4}$ concentrations,
\end{abstract}

the growth rates were higher under dry conditions while at $\mathrm{H}_{2} \mathrm{SO}_{4}$ concentrations greater than $1 \times 10^{9}$ molecule $\mathrm{cm}^{-3}$, the growth rates were higher under wet conditions. The growth rates show only a weak dependence on the residence time. The experimental observations were compared with predictions made using a numerical model, which investigates the growth of particles with three different extents of neutralization by ammonia, $\mathrm{NH}_{3}$ : (1) pure $\mathrm{H}_{2} \mathrm{SO}_{4}$ - $\mathrm{H}_{2} \mathrm{O}$ particles; (2) particles formed by ammonium bisulphate, $\left(\mathrm{NH}_{4}\right) \mathrm{HSO}_{4}$; (3) particles formed by ammonium sulphate, $\left(\mathrm{NH}_{4}\right)_{2} \mathrm{SO}_{4}$. The highest growth rates were found for ammonium sulphate particles. Since the model accounting for the initial $\mathrm{H}_{2} \mathrm{SO}_{4}$ concentration predicted the experimental growth rates correctly, our results suggest that the commonly presumed diffusional wall losses of $\mathrm{H}_{2} \mathrm{SO}_{4}$ in case of long-lasting experiments are not so significant. We therefore assume that there are not only losses of $\mathrm{H}_{2} \mathrm{SO}_{4}$ on the wall, but also a flux of $\mathrm{H}_{2} \mathrm{SO}_{4}$ molecules from the wall into the flow tube, the effect being more profound under dry conditions and at higher temperatures of the tube wall. Based on a comparison with the atmospheric observations, our results indicate that sulphuric acid alone cannot explain the growth rates of particles formed in the atmosphere. 


\section{Introduction}

Aerosol particles influence the global radiative balance and climate directly by scattering and absorbing solar radiation and indirectly by acting as condensation cloud nuclei (Charlson et al., 1992). New particle formation through the photochemical reactions of gaseous species significantly influences the number concentrations and size distributions of atmospheric aerosol. Also, aerosol models suggest that atmospheric nucleation is very likely a major source of aerosol particles in the global atmosphere (Spracklen et al., 2006) and that it is also a significant source of cloud condensation nuclei (Spracklen et al., 2008; Merikanto et al., 2009). Several mechanisms of new particle formation have been proposed, including the binary homogeneous nucleation of water and sulphuric acid (Vehkamäki et al., 2002), ternary homogeneous nucleation of water, sulphuric acid and ammonia or amines (Ball et al., 1999; Korhonen et al., 1999; Benson et al., 2009; Berndt et al., 2010; Kirkby et al., 2011), ioninduced nucleation (Lee et al., 2003; Lovejoy et al., 2004; Yu et al., 2010; Kerminen et al., 2010; Hirsikko et al., 2011) and homogeneous nucleation involving iodine species (Kulmala, 2003; O'Dowd et al., 2002b). However, it still remains unclear which mechanism is dominant in the atmosphere (Kulmala et al., 2004b), mainly because the preferred new particle formation mechanism depends on the atmospheric conditions and geographical location. Our current inability to quantify new particle formation correctly results in huge uncertainties in the assessment of the direct and indirect effects of aerosols on climate change in the climatic models (Spracklen et al., 2006; Merikanto et al., 2009).

Atmospheric nucleation is often followed by a rapid growth of freshly formed particles. The initial growth of newly formed aerosol is the crucial process determining the fraction of nucleated particles growing to cloud condensation nuclei sizes $(\sim 50 \mathrm{~nm}$ and larger) and hence subsequently participating in cloud formation processes (Dusek et al., 2006; Andreae and Rosenfeld, 2008; Kulmala and Kerminen, 2008). The majority of particle growth rates observed during atmospheric measurements lies in the range of $1-10 \mathrm{~nm} \mathrm{~h}^{-1}$, indicating that it takes about $12-72 \mathrm{~h}$ before the nucleated particles grow to cloud condensation nuclei sizes (Kulmala and Kerminen, 2008). Many recent studies have suggested that sulphuric acid plays a key role in the atmospheric nucleation and subsequent growth of newly formed particles (Sipilä et al., 2010; Brus et al., 2011a; Kirkby et al., 2011). Growth rates based entirely on the condensation of sulphuric acid vapour greatly underestimate the growth rates observed in atmospheric measurements (Sihto et al., 2006; Nieminen et al., 2010), mainly because low-volatile organic species are responsible for up to $90 \%$ of the observed growth (Mäkela et al., 2001; Smith et al., 2008). Although the growth of freshly formed particles has been intensively studied for a long time, the exact mechanism is still not well understood.
The processes governing the growth of particles in a nucleation-mode size range are condensation, selfcoagulation and coagulation scavenging (Leppä et al., 2011). After formation, the particles grow by multiple condensations of different organic and inorganic vapours (Kulmala, 2003). The condensation rate of different chemical species is influenced by the Kelvin effect, which increases the equilibrium vapour pressure with decreasing particle size and increasing molar volume of the condensing compound. According to the nano-Köhler theory (Kulmala et al., 2004a), the non-volatile and low-volatile compounds are responsible for the initial growth of freshly formed particles, and the condensation of more volatile components increases with increasing particle size (Zhang et al., 2004). Self-coagulation - coagulation between particles in the same size mode - increases the mean diameter and decreases the particle number concentration in this mode. Unless the number concentration of freshly formed particles is $1 \times 10^{6} \mathrm{~cm}^{-3}$ or higher, self-coagulation is only a minor contributor to the initial growth of nucleation-mode particles (Kulmala and Kerminen, 2008). The coagulation scavenging of nucleation-mode particles with pre-existing larger particles results in a decrease of the total particle number concentration and an increase of the diameter describing the whole aerosol population. The growth of nucleation-mode particles due to coagulation scavenging is thus only apparent because none of the particles in this mode grow larger (Leppä et al., 2011).

There are several methods to determine the particle growth rates from the atmospheric particle size distribution measurements. A data analysis method based on the fitting of the aerosol general dynamic equation to the particle size distributions has recently been introduced (Kuang et al., 2012). This approach enables, for the first time, the decoupling of the size and time dependence of particle growth rates. The growth rate of sub- $3 \mathrm{~nm}$ particles can be determined from the time lag between the increase of the concentration of sulphuric acid and the particles in the sub- $3 \mathrm{~nm}$ size range (Weber et al., 1997; Sihto et al., 2006). The maximum concentration method (Hirsikko et al., 2005) is based on investigating spectra from air ion spectrometer, in which the timing of maximum concentration in each size fraction is followed. Another method is based on the temporal evolution of the geometric mean diameters of the nucleation-mode particles, which are determined by fitting a log-normal function to the obtained particle size distributions. To determine the growth rate, a first-order polynomial is subsequently fitted to the geometric mean diameters of the nucleation mode during the new particle formation event (dal Maso et al., 2005). In laboratory studies, kinetic models or methods based on the temporal evolution of the geometric mean diameters of the measured particle size distributions are mainly used to determine the growth rates of particles formed during nucleation experiments (Young et al., 2008).

In this paper, we present the results of a laboratory study of the growth behaviour of sulphuric acid nanoparticles 
produced by nucleation of $\mathrm{H}_{2} \mathrm{SO}_{4}$ and water under wet and dry conditions. A variety of experimental conditions have been studied to assess the effect of temperature, relative humidity, residence time and $\mathrm{H}_{2} \mathrm{SO}_{4}$ concentration on the growth of freshly nucleated particles. The growth of the particles was calculated using a zero dimensional model, which was designed to simulate the processes governing the initial steps of particle growth and accounts for the condensation of sulphuric acid as well as the uptake of water and ammonia by the particles. Furthermore, three different extents of neutralization of the particles by ammonia and their growth were investigated: pure sulphuric acid-water particles, particles corresponding to an ammonium bisulphate solution and particles corresponding to an ammonium sulphate solution. The comparison of the particle growth rates determined from the different modifications of the model, as well as an analysis of the growth rates as a function of different experimental conditions is presented here.

\section{Methods}

The growth behaviour of sulphuric acid nanoparticles produced by the nucleation of sulphuric acid and water vapour was studied. The nucleation experiments were carried out in a laminar flow tube at the Finnish Meteorological Institute, Helsinki, Finland. The detailed description of the flow tube and the operational principle has been presented and discussed in detail by Brus et al. (2010) and Neitola et al. (2013).

\subsection{Measurements and experimental set-up}

The experimental set-up consists of four major parts - the saturator, mixing unit, a flow tube and particle detection device (Fig. 1). Sulphuric acid vapour was produced from a liquid reservoir by passing a stream of carrier gas through a saturator filled with high purity $\mathrm{H}_{2} \mathrm{SO}_{4}(97 \mathrm{wt} \%$, Baker Analyzed). The saturator was an iron cylinder (I.D. (inner diameter) $6 \mathrm{~cm}$ ) with Teflon insert inside. It was placed horizontally and thermally controlled using a liquid circulating bath (Lauda RC6). The temperature of the saturator was measured with a probe (PT100) just above the liquid surface. Dry, purified and particle-free air served as the carrier gas in this study. The carrier gas flow was kept at the same temperature as the saturator in order to ensure stable temperature.

Another stream of the carrier gas was dry or saturated with water vapour by passing through a set of Nafion humidifiers (MH-050, Permapure, USA). Both streams were introduced into a mixing unit and then the mixed gas stream flowed through the tube, where particles nucleated and grew to detectable sizes. The flow tube was a $200 \mathrm{~cm}$ long vertical cylinder (I.D. $6 \mathrm{~cm}$ ) made of stainless steel. The tube was thermally controlled with a liquid circulating bath (Lauda RC 6) to ensure stable temperature. At the outlet of the flow tube, the number concentrations of the produced particles were measured using an Ultrafine Condensation Particle Counter (UCPC, Model 3776, TSI Inc., USA). The same modification to UCPC TSI 3776 has been done previously, as described in Brus et al. (2010), to obtain a $d_{50}$ cut-off of $2.25 \mathrm{~nm}$. The saturator temperature was increased from a nominal $39^{\circ} \mathrm{C}$ up to $40^{\circ} \mathrm{C}$, and the condenser temperature was decreased from a nominal $10^{\circ} \mathrm{C}$ down to $8^{\circ} \mathrm{C}$. At these new temperatures no homogenous nucleation was observed inside the counter. Particle size distributions were measured using a Differential Mobility Particle Sizer (DMPS) with a short HAUKE-type Differential Mobility Analyzer (DMA), a bipolar radioactive ${ }^{63} \mathrm{Ni}$ neutralizer and UCPC (Model 3025A, TSI Inc., USA).

The measurements were performed at relative humidities of $\sim 1 \%$ and $\sim 30 \%$, presented here as dry and wet conditions respectively. The flow tube was kept at constant temperature during the measurements and the nucleation temperatures investigated were 283,293 and $303 \mathrm{~K}$. The relative humidity was measured by a humidity sensor (Vaisala HMI38) and temperature by a probe (PT100). Both lines of purified and particle-free air (saturator and mixing flow) were controlled by a mass flow rate controller to within $\pm 3 \%$ (MKS type) (Brus et al., 2010). The total gas flow inside the tube was maintained to provide four residence times in the tube: $30,45,60$ and $90 \mathrm{~s}$.

The temperature of the $\mathrm{H}_{2} \mathrm{SO}_{4}$ saturator was increased stepwise in seven increments of $5 \mathrm{~K}$ during each measurement, resulting in a gradually growing concentration of sulphuric acid in the flow tube. In order to determine the number concentration of gas-phase $\mathrm{H}_{2} \mathrm{SO}_{4}$ in the tube, the saturation vapour pressure of $\mathrm{H}_{2} \mathrm{SO}_{4}$ in the saturator was calculated first using the following equation (Kulmala and Laaksonen, 1990):

$$
\begin{aligned}
\ln p_{\mathrm{SA}} & =\ln p_{\mathrm{SA}, 0}+\frac{\Delta H_{\mathrm{v}}\left(T_{0}\right)}{R}\left[-\frac{1}{T}+\frac{1}{T_{0}}+\frac{0,38}{T_{\mathrm{c}}-T_{0}}\right. \\
& \left.\times\left(1+\ln \frac{T_{0}}{T}-\frac{T_{0}}{T}\right)\right],
\end{aligned}
$$

where $p_{\mathrm{SA}}$ is the saturation vapour pressure (atm) of $\mathrm{H}_{2} \mathrm{SO}_{4}$ at a temperature of $T(\mathrm{~K}), p_{\mathrm{SA}, 0}$ is the saturation vapour pressure of $\mathrm{H}_{2} \mathrm{SO}_{4}$ at the temperature $T_{0}=360 \mathrm{~K}$ (Ayers et al., $1980), \Delta H_{\mathrm{v}}$ is the enthalpy of vaporization, $T$ is the temperature of the saturator and $T_{\mathrm{c}}$ is the critical temperature $\left(T_{\mathrm{c}}=\right.$ $905 \mathrm{~K})$. Equation (1) is commonly used in studies of binary or ternary nucleation theories and in their parameterizations (Vehkamäki et al., 2002; Merikanto et al., 2007). Also, its accuracy has been investigated by Neitola et al. (2013) who reported a comparison of the sulphuric acid concentrations estimated using Eq. (1) and experimental concentrations measured with online ion chromatograph Monitor for AeRosols and Gases in ambient Air (MARGA; Metrohm Applikon), displaying very good agreement. The $\mathrm{H}_{2} \mathrm{SO}_{4}$ vapour concentration in the flow tube was then calculated by applying the mixing law, i.e. dividing the sulphuric acid vapour flux 

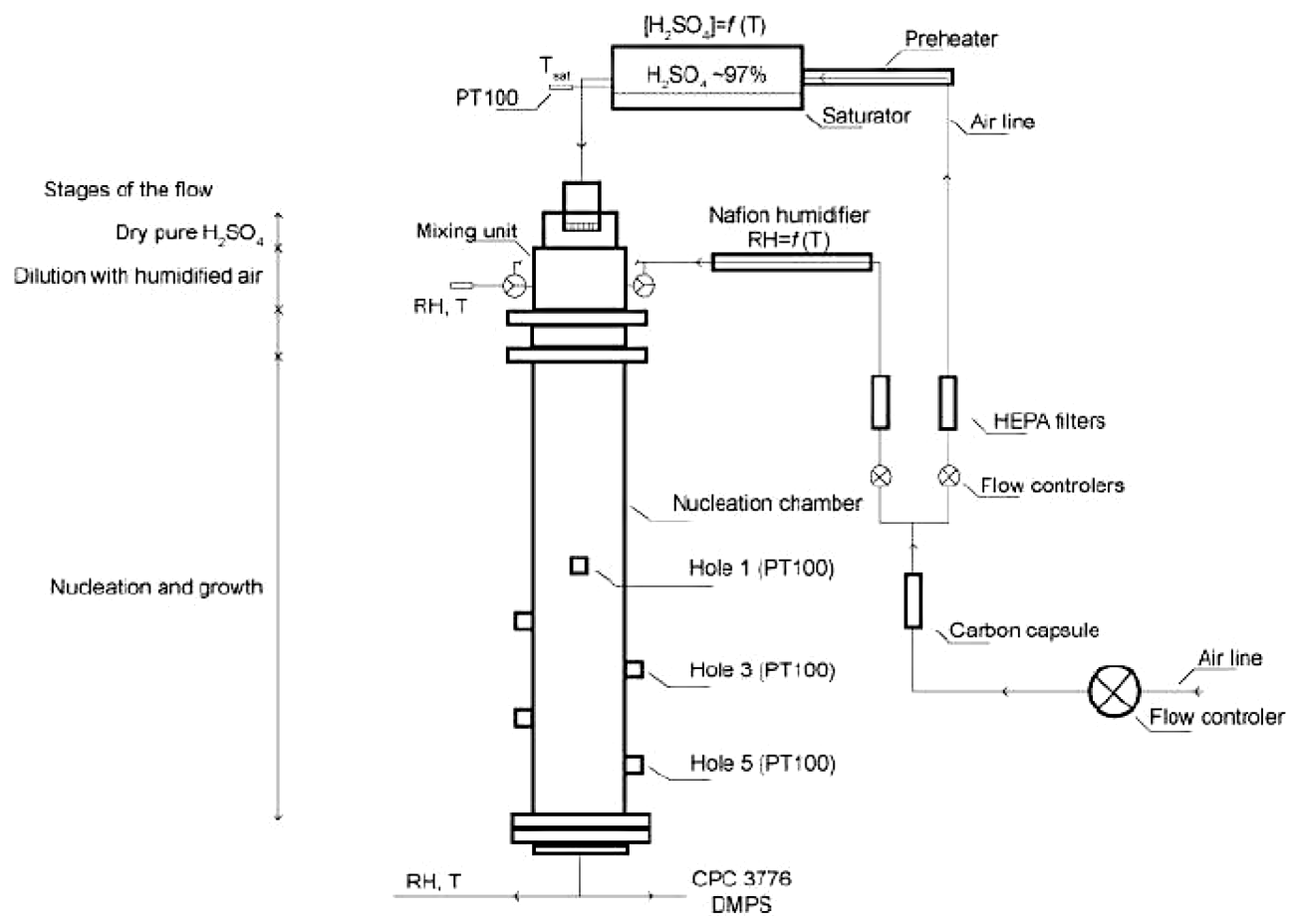

Figure 1. Schematic figure of the experimental set-up.

leaving the saturator by the total flow in the laminar flow tube. The initial concentrations of $\mathrm{H}_{2} \mathrm{SO}_{4}$, at which newly formed particles were detected during the experiments, covered the range from $2 \times 10^{8}$ to $1.4 \times 10^{10}$ molecule $\mathrm{cm}^{-3}$. The wall losses of $\mathrm{H}_{2} \mathrm{SO}_{4}$ in the flow tube were assumed to be a diffusion-controlled first-order rate process, which can be described by a simple equation given by Hanson and Eisele (2000):

$\left[\mathrm{H}_{2} \mathrm{SO}_{4}\right]_{t}=\left[\mathrm{H}_{2} \mathrm{SO}_{4}\right]_{0} e^{-k t}$,

where $\left[\mathrm{H}_{2} \mathrm{SO}_{4}\right]_{0}$ is the initial concentration of $\mathrm{H}_{2} \mathrm{SO}_{4}$, $\left[\mathrm{H}_{2} \mathrm{SO}_{4}\right]_{t}$ is the concentration after time $t$ and $k$ is the rate constant given by the equation,

$k=3.65 \frac{D}{r^{2}}$,

where $r$ is the radius of the flow tube and $D$ is the RH-dependent diffusion coefficient of $\mathrm{H}_{2} \mathrm{SO}_{4}$ (Hanson and Eisele, 2000). The diffusion coefficient $D$ for dry conditions is $D_{\text {dry }}=0.376 \mathrm{~cm}^{2} \mathrm{~s}^{-1}$ and for wet conditions $D_{\text {wet }}=0.319 \mathrm{~cm}^{2} \mathrm{~s}^{-1}$. In our experiment, $k$ was $0.0381 \mathrm{~s}^{-1}$ for dry conditions and $k$ was $0.0323 \mathrm{~s}^{-1}$ for wet conditions. In the work of Neitola et al. (2013), who used the same setup and comparable experimental conditions, the maximum condensational losses of sulphuric acid were estimated to be $1.4 \%$. Therefore condensational losses of sulphuric acid were neglected in further analysis in this study.

Although no measurement of the $\mathrm{NH}_{3}$ concentration was done during the experiments, $\mathrm{NH}_{3}$ is assumed to be present in the system (Brus et al., 2011a; Neitola et al., 2013). Since $\mathrm{NH}_{3}$ and other chemical species are ubiquitous in the ambient environment, the presence of these compounds at low concentrations cannot be excluded in the case of laboratory measurements (e.g. Benson et al., 2011, Kirkby et al., 2011). The nucleated sulphuric acid nanoparticles in our experiments are thus partially neutralized to $\left(\mathrm{NH}_{4}\right)_{2} \mathrm{SO}_{4}$ and $\left(\mathrm{NH}_{4}\right) \mathrm{HSO}_{4}$ during the measurements. The extent of the partial neutralization depends on the particle size and relative humidity, and is highest for the smallest particles and highest relative humidities (Biskos et al., 2009). In our previous study with similar set-up (Neitola et al., 2013), the concentration of ammonia was measured with the MARGA system (ten Brink et al., 2007). The average $\mathrm{NH}_{3}$ concentrations were $60 \mathrm{pptv}$ under dry conditions and $126 \mathrm{pptv}$ under wet conditions. These concentrations did not change with the increasing temperature of the saturator and thus the $\mathrm{NH}_{3}$ is assumed to originate from the carrier gas and from the ultrapure water used to humidify the mixing flow. Similar results were already reported earlier by Benson et al. (2011).

The DMPS detected particles in the size range from 3 to $200 \mathrm{~nm}$ with a time resolution of $12 \mathrm{~min}$. The uncertainties of the measured particle mode diameters were estimated to be $10 \%$ based on a comparison of the DMPS used with a standard one (Wiedensohler et al., 2012). The raw DMPS data were inverted to yield the number size distributions of the formed particles. The charging efficiencies were calculated using the parameterization of Wiedensohler and Fissan (1991). The obtained number size distributions were 
then fitted with the log-normal distribution and the geometric mean diameter of the nucleation mode was determined. The particle growth rates were then obtained from the change of the modal geometric mean as a function of time.

\subsection{Model description}

The particle growth inside the laminar flow tube was simulated with a zero dimensional model that accounts for the condensation of sulphuric acid as well as uptake of water and ammonia by the particles. The former process was modelled dynamically by calculating the mass transfer rate of sulphuric acid onto the particles, $I_{\text {SA }}$ (molecule $\mathrm{s}^{-1}$ ), using the FuchsSutugin equation (Fuchs and Sutugin, 1970):

$$
\begin{aligned}
& I_{\mathrm{SA}}=2 \pi d_{\mathrm{p}} D_{\mathrm{SA}} \mathrm{FS}(\alpha, K n)\left(C_{\mathrm{SA}}-C_{\mathrm{SA}, \mathrm{sat}}\right), \\
& \mathrm{FS}(\alpha, K n)=\frac{1+K n}{1+0.337 K n+\left(\frac{1.33}{\alpha}\right)(1+K n) K n}, \\
& K n=\frac{6 D_{\mathrm{SA}}}{c_{\mathrm{SA}} d_{\mathrm{p}}} .
\end{aligned}
$$

Here $d_{\mathrm{p}}$ is the particle diameter $(\mathrm{m}), D_{\mathrm{SA}}$ is the diffusion coefficient $\left(\mathrm{m}^{2} \mathrm{~s}^{-1}\right), \alpha$ is the mass accommodation coefficient of sulphuric acid, $C_{\mathrm{SA}}$ is the gas-phase concentration of sulphuric acid (molecule $\mathrm{cm}^{-3}$ ) and $C_{\mathrm{SA} \text {, sat }}$ is the number concentration of sulphuric acid at the saturation vapour pressure (molecule $\mathrm{cm}^{-3}$ ). Moreover, $\mathrm{FS}(\alpha, \mathrm{Kn})$ is the socalled Fuchs-Sutugin correction factor which accounts for non-continuum effects in the mass transfer, and $c_{\mathrm{SA}}\left(\mathrm{ms}^{-1}\right)$ is the mean molecular speed of sulphuric acid molecules in the gas phase. Here the value of $C_{\mathrm{SA}}$ was taken from the measurements, and $C_{\mathrm{SA} \text {, sat }}$ was set as equal to zero, corresponding to the assumption that sulphuric acid behaves as a non-volatile vapour. This assumption is reasonable for systems that contain ammonia (e.g. Kulmala et al., 2000). Finally, the value of $\alpha$ was set as equal to unity based on the measurements conducted by Hanson (2005).

The uptake of the considered semi-volatile compounds, ammonia and water, was modelled as follows. First, since there were no direct measurements of the ammonia concentration levels in the system, we applied three different degrees of particle neutralization: (1) no ammonia was assumed to be taken up by the aerosols, (2) ammonia was assumed to condense along with sulphuric acid so that a $1: 1$ molar ratio was maintained between ammonia and sulphuric acid, corresponding thus to an ammonium bisulphate solution, and (3) two ammonia molecules were assumed to condense for each acid molecule which corresponds to an ammonium sulphate solution. The particles were assumed to be aqueous regardless of the relative humidity, and the particle water content was calculated as a function of the water activity $\left(a_{\mathrm{w}}\right)$ using the appropriate molality data found in the literature (Staples, 1981 for sulphuric acid; Tang and Munkelwitz, 1994 for ammonium-bisulphate and ammonium-sulphate). Here the water activity $a_{\mathrm{w}}$ was calculated according to the relation
$a_{\mathrm{w}}=\mathrm{RH} / \mathrm{Ke}$ where RH is the relative humidity in the instrument and Ke is the Kelvin term (Seinfeld and Pandis, 1998). Finally, the particle surface tension and density were calculated using the model presented by Hyvärinen et al. (2005).

The initial particle diameter $d_{\text {init }}$ (corresponding to the median diameter obtained from fitting of DMPS size distributions obtained from measurement at the lowest temperature of the saturator) was taken from the measurements, and the initial chemical composition was set so that the particles were in equilibrium with respect to water and ammonia. The increase of the particle diameter as a function of the increasing sulphuric acid concentration (temperature of the saturator) was then simulated. Also, the particle size was increased after each time step by first converting the total particle mass (obtained as described above) to a corresponding volume and further to a diameter $d_{\mathrm{p}}$ by assuming that the particles are spherical. At the end of the simulation, the "effective" growth rate of particles over the experiment, GR, was calculated as follows:

$\mathrm{GR}=\frac{d_{\mathrm{p}}-d_{\text {init }}}{t_{\exp }}$,

where $d_{\mathrm{p}}$ is the particle diameter at the end of the experiment and $t_{\exp }$ is the residence time in the laminar flow tube. The applied time step was $0.1 \mathrm{~s}$ in all of the performed calculations.

\section{Results and discussion}

\subsection{Reproducibility of the measurements}

The reproducibility of the performed measurements is illustrated in Figs. 2a and b, which show the results of experiments at a temperature of $283 \mathrm{~K}$, a residence time of $60 \mathrm{~s}$ and under dry conditions ( $\mathrm{RH} \sim 1 \%$ ), taken 1 day apart. The total particle concentrations as a function of the $\mathrm{H}_{2} \mathrm{SO}_{4}$ concentration measured by DMPS for both experiments are presented in Fig. 2a. Except the first points, which show larger scatter and with a ratio of these concentrations of $1: 1.17$, the ratios of the remaining concentrations range from $1: 1.01$ to $1: 1.07$. The observed variation of the median particle diameters as a function of the initial $\mathrm{H}_{2} \mathrm{SO}_{4}$ concentrations with standard deviations as error bars is shown in Fig. 2b. At the same temperature, relative humidity, residence time and comparable $\mathrm{H}_{2} \mathrm{SO}_{4}$ concentrations, the maximum difference of single median particle diameters determined from both experiments was $0.6 \mathrm{~nm}$, with most diameters varying by 0.3 or $0.4 \mathrm{~nm}$. These results show that the measurements of the particle diameters and particle number concentrations were very reproducible. 

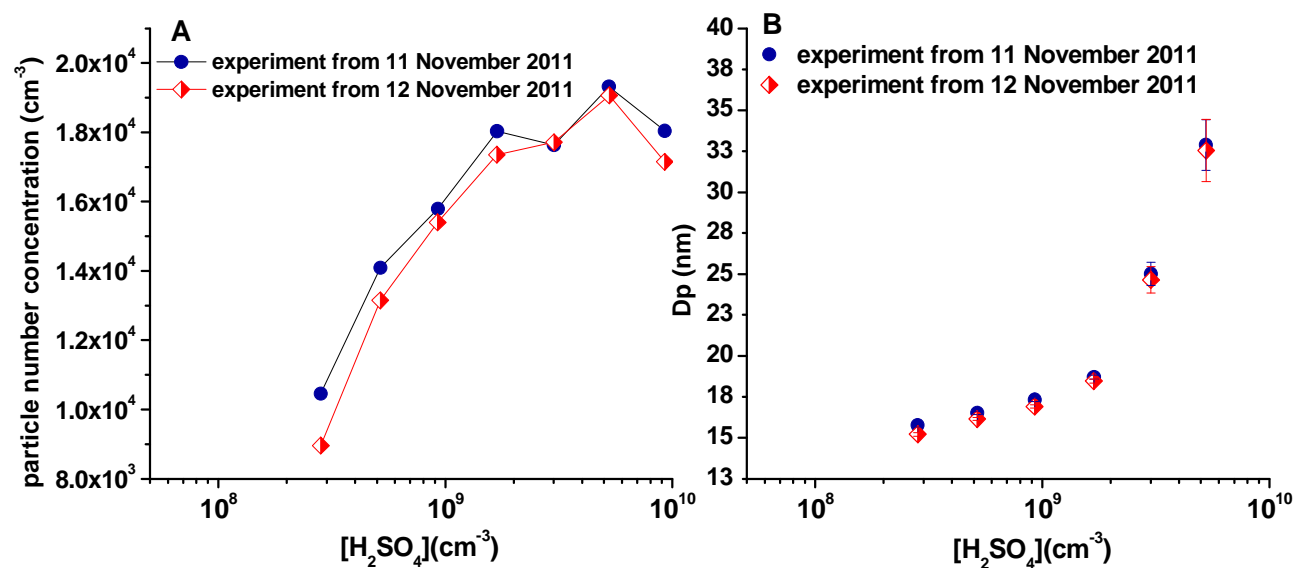

Figure 2. The variation of the total particle concentrations determined from a DMPS from measurements performed at $T=283 \mathrm{~K}$, with an $\mathrm{RH}$ of $\sim 1 \%$ and a residence time of $60 \mathrm{~s}$, taken 1 day apart. Fig. $2 \mathrm{~b}$ : the median particle diameters determined from measurements performed at $T=283 \mathrm{~K}$, with an $\mathrm{RH}$ of $\sim 1 \%$ and a residence time of $60 \mathrm{~s}$, taken 1 day apart. The standard deviations of the median particle diameters are depicted as error bars.

\subsection{Variation of particle number concentrations and particle size distributions}

During each experiment the temperature of the saturator was increased in seven consecutive steps of $5 \mathrm{~K}$ every $2 \mathrm{~h}$, resulting in a distinct increase of the $\mathrm{H}_{2} \mathrm{SO}_{4}$ concentration in the gas phase and a subsequent significant rise of the particle number concentration. The stability of particle production was not achieved immediately; it took approximately $30 \mathrm{~min}$ to obtain a steady particle production. The first $30 \mathrm{~min}$ of every period of constant saturator temperature were therefore excluded from the analysis. The data from the DMPS were then averaged over the whole period analysed to receive a single data point characterizing each saturator temperature, and the data from the UCPC were averaged over two equal periods of $45 \mathrm{~min}$ to receive two data points.

The determined curves of the particle number concentration, as a function of the initial $\mathrm{H}_{2} \mathrm{SO}_{4}$ concentration measured by both DMPS and UCPC at $T=293 \mathrm{~K}, \mathrm{RH} \sim 30 \%$ and at residence times of 45,60 and $90 \mathrm{~s}$, are presented in Fig. 3. The total number concentrations determined from both instruments were found to be strongly dependent on the residence time of the gaseous mixture in the flow tube. The significance of residence time in nucleation measurements has been discussed in previous studies (Sipilä et al., 2010; Berndt et al., 2010). The results clearly show that the observed total number concentration is influenced by the growth process and the longer the residence time, the larger the fraction of nucleated particles grows beyond the detection limits of the UCPC and DMPS. For example, during the experiment performed at $T=293 \mathrm{~K}$ and $\mathrm{RH} \sim 30 \%$, at a $\mathrm{H}_{2} \mathrm{SO}_{4}$ concentration of $6.5 \times 10^{8}$ molecule $\mathrm{cm}^{-3}$, the particle number concentration increases about one order of magnitude, from $3.2 \times 10^{3} \pm 0.15 \times 10^{3} \mathrm{~cm}^{-3}$ at a residence time of $45 \mathrm{~s}$ to $3 \times 10^{4} \pm 1.1 \times 10^{3} \mathrm{~cm}^{-3}$ at a residence time of

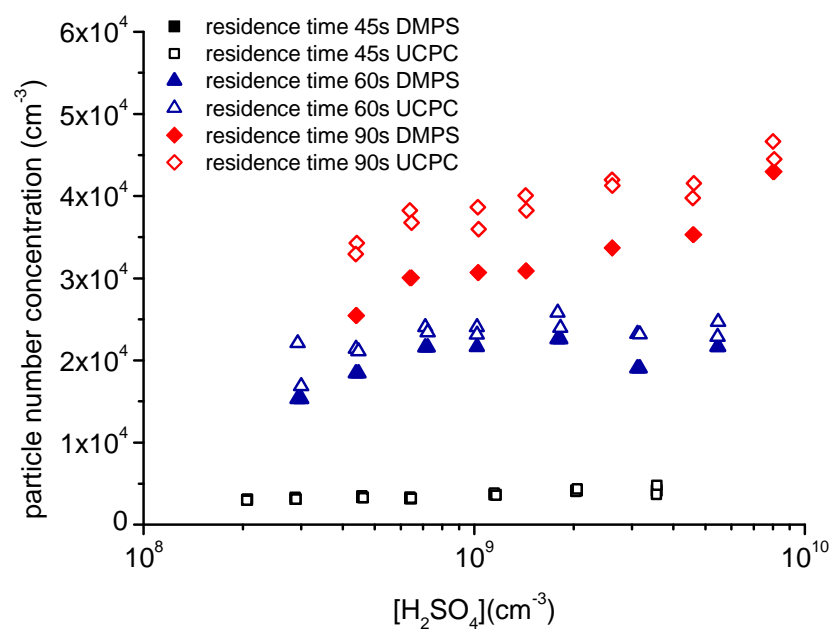

Figure 3. The observed particle number concentrations at different residence times at $T=293 \mathrm{~K}$ and with an RH of $\sim 30 \%$. The solid symbols present the number concentrations determined by a DMPS and the open symbols are number concentrations determined by a UCPC.

90 s. Absolutely no particles were detected during experiments performed at a residence time of $30 \mathrm{~s}$, indicating that the nucleated particles were not able to grow to detectable sizes during the first $30 \mathrm{~s}$ of the experiments. The particle number concentrations at all residence times were rather stable at any $\mathrm{H}_{2} \mathrm{SO}_{4}$ concentration (see Fig. 3). The total particle concentrations obtained from the DMPS measurements were slightly lower than the values detected with the standalone UCPC, which was due to the lower cut-off diameter $\left(d_{50}=2.25 \mathrm{~nm}\right)$ of the stand-alone UCPC (Brus et al., 2010) and the upper limit $(200 \mathrm{~nm})$ of the DMPS which undercounts at higher sulphuric acid concentrations (Fig. 3). By 


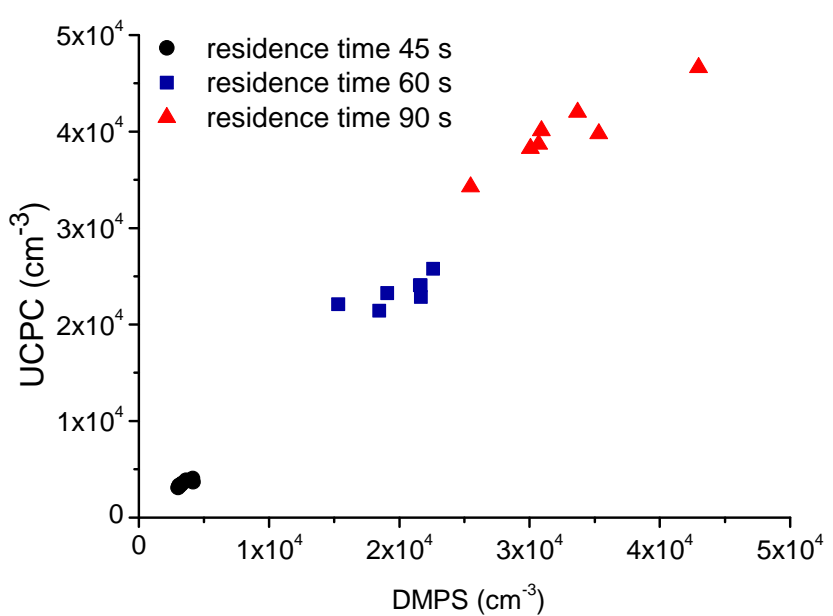

Figure 4. An almost linear relationship was reached by a comparison of the particle number concentrations determined from a DMPS and a UCPC at different residence times, at $T=293 \mathrm{~K}$ and with the $\mathrm{RH}$ set at $30 \%$.

comparing the measurements from both instruments, we received an almost linear relationship between the concentrations in most cases, which can be seen in Fig. 4. A visible decrease of the particle concentration at the temperature of the saturator, $295 \mathrm{~K}$, corresponding to the $\mathrm{H}_{2} \mathrm{SO}_{4}$ concentration of $\sim 3.5 \times 10^{9}$ molecule $\mathrm{cm}^{-3}$ recorded by UCPC, can be seen in Fig. 3. This artefact of the experimental set-up was observed when the temperature of the acid saturator was close to the temperature of the mixing unit ( $\sim 293 \mathrm{~K})$, and this behaviour was also reported in our previous study with a very similar set-up (Neitola et al., 2013).

The observed variation in the particle size distributions obtained from the inversion of the raw DMPS data from a single experiment - a measurement performed at a constant nucleation temperature of $T=283 \mathrm{~K}$, a residence time of $60 \mathrm{~s}$, an $\mathrm{RH}$ of $\sim 30 \%$ and at different $\mathrm{H}_{2} \mathrm{SO}_{4}$ concentrations is presented in Fig. 5. The increasing total particle concentration and particle median diameter correspond with the increasing $\mathrm{H}_{2} \mathrm{SO}_{4}$ concentration in the gaseous mixture. The values of the total number concentrations during all of the measurements ranged from $1.1 \times 10^{3} \pm 0.17 \times 10^{3} \mathrm{~cm}^{-3}$ to $4.7 \times 10^{4} \pm 1.2 \times 10^{3} \mathrm{~cm}^{-3}$, and were generally higher during experiments performed at $\mathrm{RH}$ of $\sim 30 \%$ and nucleation temperature of $303 \mathrm{~K}$. The values of the median particle diameter ranged from $14.4 \pm 0.1 \mathrm{~nm}$ to $39.8 \pm 1.6 \mathrm{~nm}$ and particles grew larger at an $\mathrm{RH}$ of $\sim 30 \%$ and at high $\mathrm{H}_{2} \mathrm{SO}_{4}$ concentrations.

\subsection{Growth of the particles under dry and wet conditions}

The $\mathrm{H}_{2} \mathrm{SO}_{4}-\mathrm{H}_{2} \mathrm{O}$ nucleation was affected by the presence of impurities originating from ultra-pure water and carrier gas. The enhancing effect of $\mathrm{NH}_{3}$ on nucleation was observed in

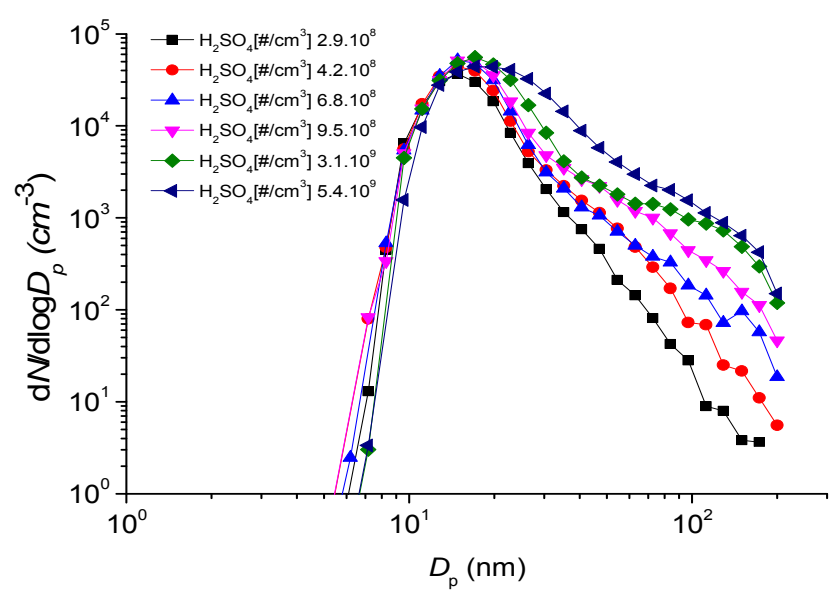

Figure 5. The variation in the median particle diameters at different $\mathrm{H}_{2} \mathrm{SO}_{4}$ concentrations at $T=283 \mathrm{~K}$, with the $\mathrm{RH}$ set at $30 \%$ and a residence time of $60 \mathrm{~s}$.

the laboratory experiments and was found to be stronger at low relative humidities (Berndt et al., 2010; Benson et al., 2011). The freshly formed $\mathrm{H}_{2} \mathrm{SO}_{4}$ particles are partially neutralized to ammonium bisulphate, $\left(\mathrm{NH}_{4}\right) \mathrm{HSO}_{4}$, and ammonium sulphate, $\left(\mathrm{NH}_{4}\right)_{2} \mathrm{SO}_{4}$. For a fixed relative humidity, the hygroscopic growth of these particles was found to decrease with decreasing particle size owing to a greater degree of neutralization, since $\left(\mathrm{NH}_{4}\right)_{2} \mathrm{SO}_{4}$ is less hygroscopic than $\mathrm{H}_{2} \mathrm{SO}_{4}$ (Biskos et al., 2009). When considering the effect of water vapour on the particle growth, the hydration of $\mathrm{H}_{2} \mathrm{SO}_{4}$ should be taken into account. The number of water molecules attached to an $\mathrm{H}_{2} \mathrm{SO}_{4}$ molecule increases significantly with the growing relative humidity and the higher the relative humidity, the higher the growth rate due to the condensation of $\mathrm{H}_{2} \mathrm{O}$ on the particles (Nieminen at al., 2010).

The variation of the particle diameters has the same pattern under both wet and dry conditions, which is illustrated in Fig. 6. Hygroscopic growth behaviour can be described with the so-called hygroscopic growth factor (GF),

$\mathrm{GF}=\frac{D_{\mathrm{p}}(\mathrm{wet})}{D_{\mathrm{p}}(\mathrm{dry})}$.

In this study, the dry diameters $D_{\mathrm{p}}$ (dry) corresponds to the median particle diameters obtained from measurements performed at an RH of $\sim 1 \%$, and the wet diameters $D_{\mathrm{p}}$ (wet) to the median particle diameters obtained from measurements at an RH of $\sim 30 \%$. Hygroscopic growth factors determined from measurements performed at $T=293 \mathrm{~K}$ ranged from 1.05 to 1.35 and at $T=303 \mathrm{~K}$ the values covered the range from 1.1 to 1.42 . Our findings were then compared with the results from Biskos et al. (2010), who measured the hygroscopic growth of acidic sulphate nanoparticles over a wide range of relative humidities using the tandem DMA technique. At a relative humidity of $\sim 30 \%$, Biskos et al. (2010) reported for dry diameters from $7.5 \mathrm{~nm}$ to $36.1 \mathrm{~nm}$, which 


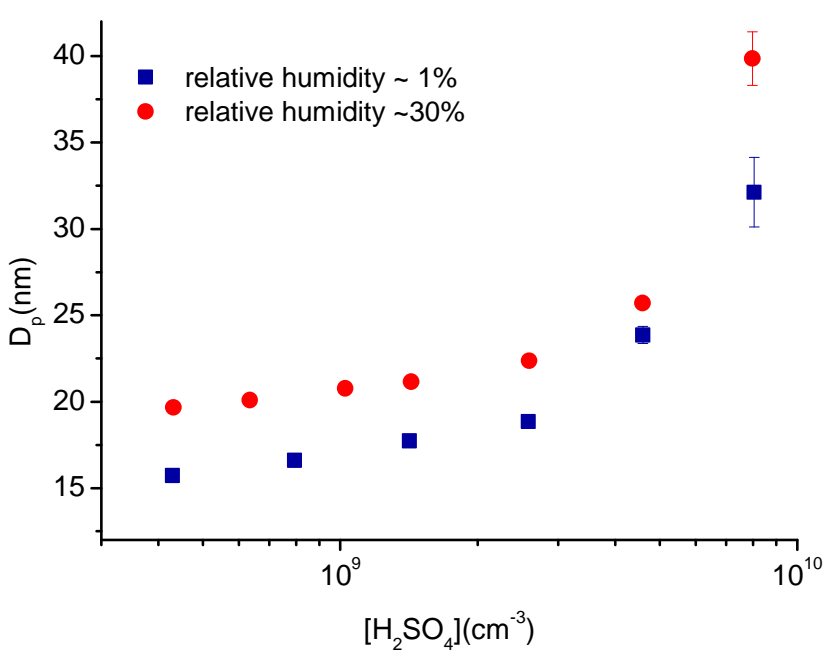

Figure 6. The variation in the median particle diameters determined from measurements performed at $T=303 \mathrm{~K}$, with a residence time of $60 \mathrm{~s}$ and at different RH. The standard deviations of the median particle diameters are depicted as error bars.

are comparable with this study, growth factors from 1.18 to 1.3 . The best agreement with our study was found for $T=303 \mathrm{~K}$, since most $\mathrm{GF}$ values determined at this temperature were close to 1.25 , which is illustrated in Fig. 7. At $T=293 \mathrm{~K}$ most GFs (growth factors) were around 1.1 and reached values above 1.2 only at a residence time of $90 \mathrm{~s}$ and for $\mathrm{H}_{2} \mathrm{SO}_{4}$ concentrations of $5 \times 10^{9}$ molecule $\mathrm{cm}^{-3}$ and higher (Fig. 7). The hygroscopic growth factors were not determined for $T=283 \mathrm{~K}$, since the differences in the determined median particle diameters from measurements under wet and dry conditions at all residence times were so small that in most cases they fell within the uncertainty range of the measurements. A clear dependence of GFs on $\mathrm{H}_{2} \mathrm{SO}_{4}$ concentration can be seen in Fig. 7. At the lowest applied $\mathrm{H}_{2} \mathrm{SO}_{4}$ concentrations at $293 \mathrm{~K}$, the GFs slightly decrease with increasing $\mathrm{H}_{2} \mathrm{SO}_{4}$ while the opposite trend was observed at the concentration range above $\sim 3 \times 10^{9}$ molecule $\mathrm{cm}^{-3}$. However, the GFs calculated from our model were not in good agreement with the experimental values, since it predicted higher GFs $(\sim 15 \%$ higher at $T 293 \mathrm{~K}$ and $\sim 25 \%$ higher at $T 303 \mathrm{~K}$ ) and also predicted different trend in GFs behaviour. For this reason, it could not be explained if the trends in the GFs behaviour are real or spurious. The changing behaviour of the growth factors could be explained by a larger fraction of acidic and therefore more hygroscopic particles at higher $\mathrm{H}_{2} \mathrm{SO}_{4}$ concentrations.

\subsection{Wall losses of sulphuric acid}

The initial concentrations of $\mathrm{H}_{2} \mathrm{SO}_{4}$, at which newly formed particles were detected during the experiments, covered the range from $1.8 \times 10^{8}$ to $1.4 \times 10^{10}$ molecule $\mathrm{cm}^{-3}$. Previous nucleation experiments, conducted with $\mathrm{H}_{2} \mathrm{SO}_{4}$ produced

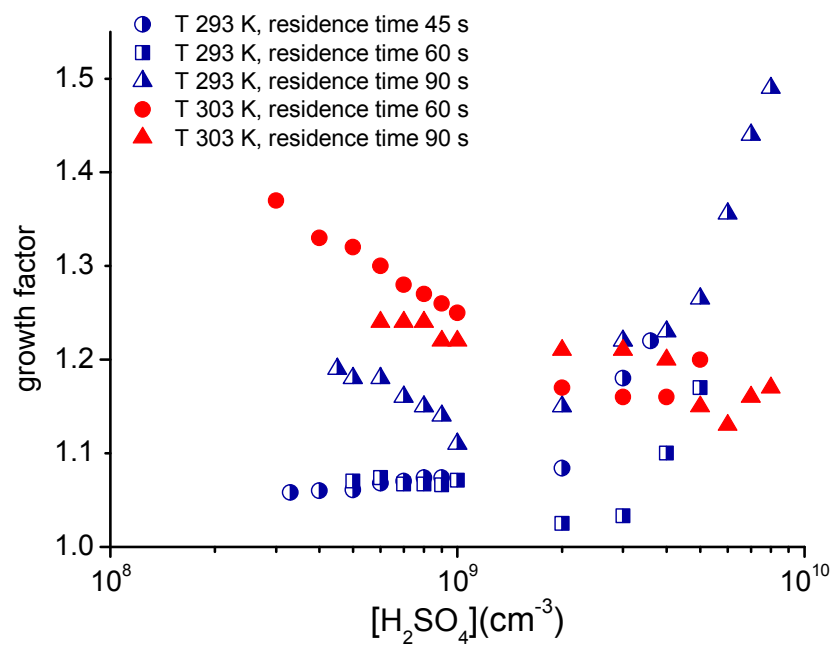

Figure 7. The growth factors as a function of the $\mathrm{H}_{2} \mathrm{SO}_{4}$ concentration at $T=293$ and $T=303 \mathrm{~K}$ at different residence times.

from a liquid reservoir, reported that nucleation occurred at an $\mathrm{H}_{2} \mathrm{SO}_{4}$ concentration of $\sim 10^{9}$ molecule $\mathrm{cm}^{-3}$ and higher (Wyslouzil et al., 1991; Viisanen et al., 1997; Ball et al., 1999; Zhang et al., 2004). The $\mathrm{H}_{2} \mathrm{SO}_{4}$ molecules can attach to the inner surfaces of the flow tube during experiments, and in order to determine the residual concentration of $\mathrm{H}_{2} \mathrm{SO}_{4}$ the corrections of the initial concentrations are necessary. The wall loss factor characterizing the diffusion losses of sulphuric acid on the walls of the tube is defined as follows:

$\mathrm{WLF}=\frac{\left[\mathrm{H}_{2} \mathrm{SO}_{4}\right]_{0}}{\left[\mathrm{H}_{2} \mathrm{SO}_{4}\right]_{t}}$,

where $\left[\mathrm{H}_{2} \mathrm{SO}_{4}\right]_{0}$ is the initial concentration of sulphuric acid in the flow tube determined from Eq. (1) and $\left[\mathrm{H}_{2} \mathrm{SO}_{4}\right]_{t}$ is the concentration of sulphuric acid after time $t$. In this study, the time, $t$, was set as equal to half of the residence time of the gaseous mixture in the flow tube, and thus the concentration $\left[\mathrm{H}_{2} \mathrm{SO}_{4}\right]_{t}$ corresponds approximately to the $\mathrm{H}_{2} \mathrm{SO}_{4}$ concentration in the middle of the flow tube. This assumption was based on our previous studies where the nucleation zone was determined experimentally (Brus et al., 2010) and also verified by the computational fluid dynamics (CFD) model (Herrmann et al., 2010). It should be noted that the experimental set-up in the previous study was different from this work a furnace was used instead of saturator and thus temperature gradient was introduced at the beginning of the flow tube. The wall losses were determined according to Hanson and Eisele (2000) and the wall loss factors span the range from 1.9 to 4.8 under wet conditions and from 2.2 to 6.2 under dry conditions for a $t$ from 22 to $45 \mathrm{~s}$, calculated as half of the initial residence times.

However, when using the calculated $\mathrm{H}_{2} \mathrm{SO}_{4}$ concentrations corrected by WLFs (wall loss factors) as an input parameter in our model, the experimental values did not agree 


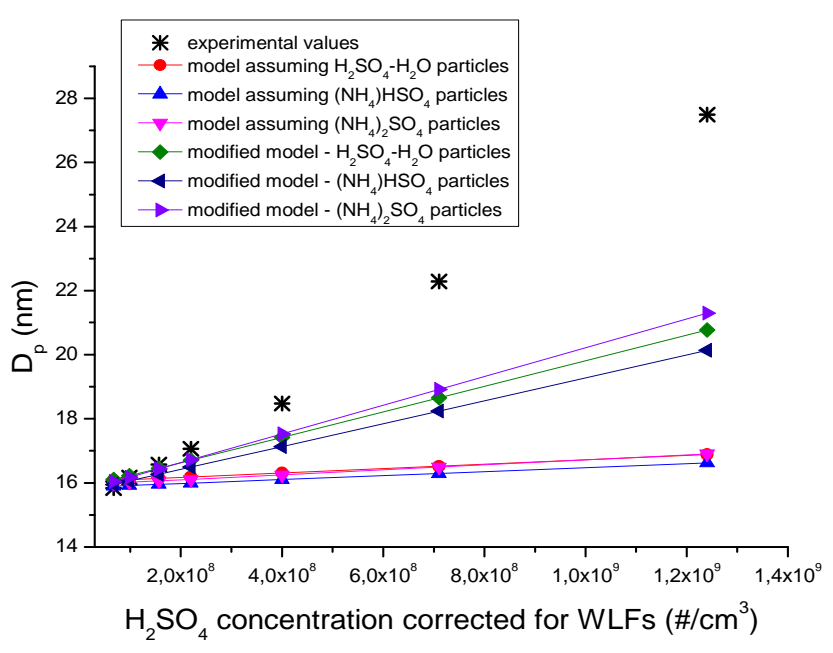

Figure 8. The comparison of the experimental median particle diameters from a measurement conducted at $T=283 \mathrm{~K}$, with an RH of $\sim 30 \%$ and a residence time of $60 \mathrm{~s}$, values predicted theoretically from a model using the $\mathrm{H}_{2} \mathrm{SO}_{4}$ concentration corrected for wall losses, determined according to Hanson and Eisele (2000) and a modified model, accounting for a system-specific wall loss coefficients (Brus et al., 2011b).

with the theoretical predictions. This can be seen from Fig. 8 which illustrates the variation of both the measured and calculated median particle diameters at an $\mathrm{RH}$ of $\sim 30 \%$, with $T=283 \mathrm{~K}$ and a residence time of $60 \mathrm{~s}$. The model fails to capture the observed growth rates in all cases since it predicts significantly lower particle growth than that observed in experiments, and the deviations are more profound at an $\mathrm{RH}$ of $\sim 1 \%$ and with high $\mathrm{H}_{2} \mathrm{SO}_{4}$ concentrations. These results suggest that the $\mathrm{H}_{2} \mathrm{SO}_{4}$ concentration corresponding to the middle of the flow tube is too low and does not describe the growth behaviour of the particles correctly. For this reason, the initial $\mathrm{H}_{2} \mathrm{SO}_{4}$ concentration corresponding to the $\mathrm{H}_{2} \mathrm{SO}_{4}$ concentration at the beginning of the flow tube was used as the input parameter for all the model calculations in the further analysis.

Although the particles are assumed to nucleate at the beginning of the flow tube in this study, the nucleation can also occur in some distance along the tube. The uncertainty of the calculated growth rates resulting from the nucleation zone location was estimated as the difference between growth rates calculated assuming nucleation at the beginning of the flow tube and growth rates assuming the nucleation occurring $50 \mathrm{~cm}$ from the beginning of the flow tube (the total length of the flow tube is $2 \mathrm{~m}$ ). The calculated uncertainties are $7.5 \%$ for residence time $45 \mathrm{~s}, 10 \%$ for residence time $60 \mathrm{~s}$ and $15 \%$ for residence time $90 \mathrm{~s}$. The system-specific wall loss coefficients were used in these calculations (see explanation below).

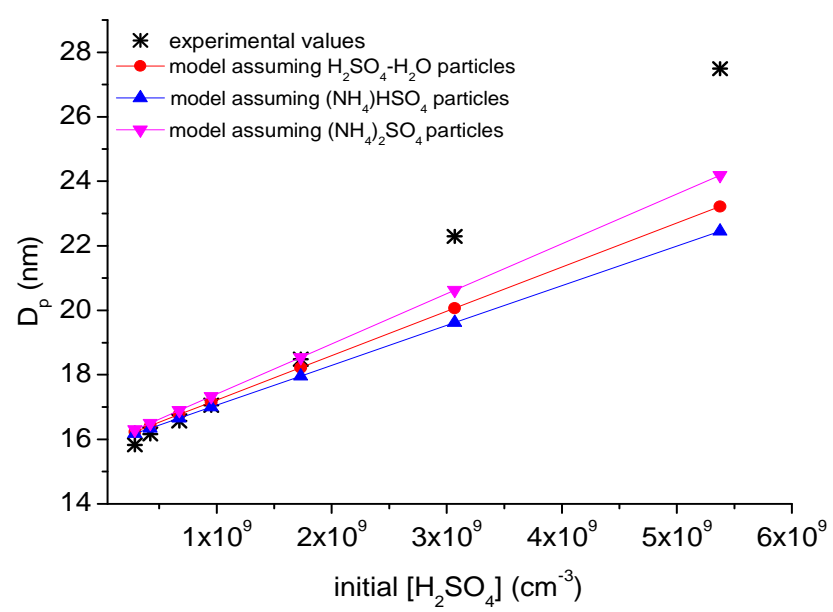

Figure 9. The comparison of the experimental median particle diameters from a measurement conducted at $T=283 \mathrm{~K}$, with an $\mathrm{RH}$ of $\sim 30 \%$ and a residence time of $60 \mathrm{~s}$, and the values predicted theoretically from a model using the initial $\mathrm{H}_{2} \mathrm{SO}_{4}$ concentration without a correction for wall losses.

\subsection{The particle growth rates and model evaluation}

The growth of freshly formed particles was calculated using the numerical model described in Sect. 2.2. By including the initial $\mathrm{H}_{2} \mathrm{SO}_{4}$ concentration determined from Eq. (1) in the model, we achieved much better agreement with the experimental data as compared to the results based on the $\mathrm{H}_{2} \mathrm{SO}_{4}$ concentrations corrected for wall losses (Hanson and Eisele, 2000). In order to investigate this discrepancy, additional calculations were performed using the same model accounting for system-specific wall loss coefficients $\left(0.0047 \mathrm{~cm}^{-1}\right.$ for wet conditions and $0.0061 \mathrm{~cm}^{-1}$ for dry conditions) determined for the flow tube in our previous study (Brus et al., 2011b). A comparison of the experimental and numerical results is illustrated in Fig. 9, which shows the experiment conducted at $T=283 \mathrm{~K}$, an RH of $\sim 30 \%$ and a residence time of $60 \mathrm{~s}$ (compare with Fig. 8). As can be seen there, the calculations agree very well with the experimental data, despite the fact that the model slightly overestimates the growth rates at a residence time of $90 \mathrm{~s}$, at all temperatures and under both wet and dry conditions (Fig. 10). Also using the system-specific wall loss coefficients provides much better agreement with experimental data compared to calculations based on wall loss coefficients according to Hanson and Eisele (2000) (see Fig. 8). The results may also be influenced by different carrier gases - Hanson and Eisele (2000) used nitrogen in their work, whereas in our studies particlefree and purified air was used as the carrier gas (the diffusion of $\mathrm{H}_{2} \mathrm{SO}_{4}$ in air is slower compared to diffusion of $\mathrm{H}_{2} \mathrm{SO}_{4}$ in nitrogen).

It should be noted that the model accounts only for $\mathrm{H}_{2} \mathrm{SO}_{4}$, water and ammonia while different impurities may have been present in our system in trace concentrations. Such 


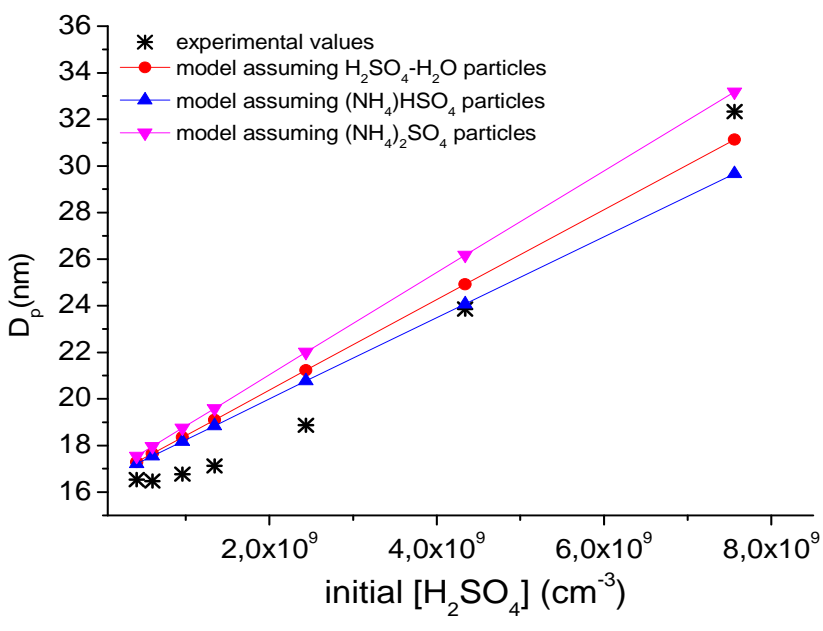

Figure 10. The comparison of the experimental median particle diameters determined from a measurement conducted at $T=283 \mathrm{~K}$, with an $\mathrm{RH}$ of $\sim 30 \%$ and a residence time of $90 \mathrm{~s}$, and the values predicted theoretically from a model using the initial $\mathrm{H}_{2} \mathrm{SO}_{4}$ concentration without a correction for wall losses. As can be seen, the model overestimates the growth rates slightly in the case of experiments conducted at a residence time of $90 \mathrm{~s}$.

compounds might have influenced the nucleation process and the subsequent growth of the freshly formed particles. The impurities (amines and other organics) were measured by MARGA in the same experimental set-up several times (see Neitola et al., 2013), and their levels were always below detection limits (for amines $\sim 100 \mathrm{pptv}$ ). In spite of that, we cannot rule out the presence of the impurities in the flow tube and their influence on growth dynamics. The assumed presence of ammonia and its role in the growth process is addressed in the model, accounting for three degrees of neutralization of formed particles by ammonia. Amines, more specifically alkylamines, which usually accompany ammonia in one order lower concentrations, can displace ammonia from ammonium sulfate and create alkylaminium sulfates (Zhang et al., 2012; Ge et al., 2011). Alkylaminium sulfates have comparable properties to ammonium sulfate and are even more stable in the particle phase; also, aerosol dynamics are very similar to that of ammonium sulphate and ammonium bisulphate (Qiu and Zhang, 2012).

An indirect way to determine the $\mathrm{H}_{2} \mathrm{SO}_{4}$ concentration in experimental devices is based on the measured growth rates of the freshly formed particles. The $\mathrm{H}_{2} \mathrm{SO}_{4}$ concentrations in our study, derived solely from the growth rates determined experimentally and verified in our model, indicate that the commonly assumed wall losses of $\mathrm{H}_{2} \mathrm{SO}_{4}$ on the inner surfaces calculated from Eq. (2) are not as significant in case of long-lasting experiments as previously believed. Using the system-specific wall loss coefficients in our model provides good agreement with experimental data, especially at lower acid concentrations. This indicates that in our experiments the sulphuric acid wall losses were substantially lower than predicted according to a commonly used expression from Hanson and Eisele (2000). We therefore speculate that due to close to wall-equilibrium conditions, the wall is not an infinite sink for $\mathrm{H}_{2} \mathrm{SO}_{4}$, but that there is also a flux of $\mathrm{H}_{2} \mathrm{SO}_{4}$ from the wall to the flow tube. For example, in the study by Hanson and Eisele (2000), the wall of a laminar flow tube was found to be a significant source of $\mathrm{H}_{2} \mathrm{SO}_{4}$ at an $\mathrm{RH}$ of $<0.5 \%$, and the concentration of $\mathrm{H}_{2} \mathrm{SO}_{4}$ from the wall reached up to $3 \times 10^{8}$ molecule $\mathrm{cm}^{-3}$. Another possible explanation for the discrepancy between the $\mathrm{H}_{2} \mathrm{SO}_{4}$ concentrations calculated from Eq. (2) and that derived from our experimental growth rates might be the limited adsorption capacity of the wall. The wall becomes saturated with $\mathrm{H}_{2} \mathrm{SO}_{4}$ during experiments, and therefore further adsorption of $\mathrm{H}_{2} \mathrm{SO}_{4}$ molecules might be hindered after a certain time period. We estimated the "real" wall losses of $\mathrm{H}_{2} \mathrm{SO}_{4}$ by matching the predicted and observed growth rates through tuning the initial $\mathrm{H}_{2} \mathrm{SO}_{4}$ concentration in the model. Although the estimated wall losses were slightly scattered for different experimental conditions (RH, temperature and residence time), a reasonable agreement found for the experimental and modelled data yields an estimation of the wall losses: $\sim 10 \%$ for a residence time of $45 \mathrm{~s}, \sim 15 \%$ for a residence time of $60 \mathrm{~s}$ and $\sim 25 \%$ for a residence time of $90 \mathrm{~s}$, corresponding to WLFs of $1.11,1.18$ and 1.33 , respectively.

The experimental growth rates, determined from Eq. (7), range from $20 \mathrm{~nm} \mathrm{~h}^{-1}$ to $890 \mathrm{~nm} \mathrm{~h}^{-1}$ under dry conditions and from $7 \mathrm{~nm} \mathrm{~h}^{-1}$ to $980 \mathrm{~nm} \mathrm{~h}^{-1}$ under wet conditions. When analysing the dependence on the experimental conditions, the measured growth rates were found to increase with growing $\mathrm{H}_{2} \mathrm{SO}_{4}$ concentration and increased almost linearly with increasing particle size. Also, increases in the nucleation temperature were found to have a slight enhancing effect on particle growth rates under dry conditions. At a very low $\mathrm{RH}$, the wall is a source of $\mathrm{H}_{2} \mathrm{SO}_{4}$ molecules and the flux is proportional to the $\mathrm{H}_{2} \mathrm{SO}_{4}$ vapour pressure, which increases with rising temperature. The influence of the $\mathrm{RH}$ is not consistent - at lower $\mathrm{H}_{2} \mathrm{SO}_{4}$ concentrations the growth rates were higher under dry conditions, at $\mathrm{H}_{2} \mathrm{SO}_{4}$ concentrations of $\sim 1 \times 10^{9}$ molecule $\mathrm{cm}^{-3}$ and above, the growth rates were higher under wet conditions. This effect could be partially explained by the displacement reaction of alkylamines with ammonium sulphate to form alkylaminium sulphates. This reaction causes the transition from crystalline to an amorphous phase (Qui and Zhang, 2012), which enhances water uptake and consequently particle growth with increasing $\mathrm{RH}$. The residence time was found to have a negligible effect on the measured growth rates.

The predicted growth rates, calculated from the model with the initial $\mathrm{H}_{2} \mathrm{SO}_{4}$ concentration using Eq. (7), range from $7 \mathrm{~nm} \mathrm{~h}^{-1}$ to $1100 \mathrm{~nm} \mathrm{~h}^{-1}$ under dry conditions and from $15 \mathrm{~nm} \mathrm{~h}^{-1}$ to $1300 \mathrm{~nm} \mathrm{~h}^{-1}$ under wet conditions. Growth rates over $1000 \mathrm{~nm} \mathrm{~h}^{-1}$ were reached only at very high $\mathrm{H}_{2} \mathrm{SO}_{4}$ concentrations of $8 \times 10^{9}$ molecule $\mathrm{cm}^{-3}$ and higher, and at a residence time of $90 \mathrm{~s}$. Most growth rates span the 
range from $\sim 10 \mathrm{nmh}^{-1}$ to $\sim 500 \mathrm{~nm} \mathrm{~h}^{-1}$ under dry conditions and from $\sim 15 \mathrm{~nm} \mathrm{~h}^{-1}$ to $\sim 400 \mathrm{~nm} \mathrm{~h}^{-1}$ under wet conditions. Our model considered three different numbers of $\mathrm{NH}_{3}$ molecules taken up by each molecule of $\mathrm{H}_{2} \mathrm{SO}_{4}$ during particle formation. All three tested degrees of neutralization provided results that are in good agreement with the experimental data and all of them capture the trends in the growth rate values in a similar manner (see Fig. 9). The highest growth rates were achieved for ammonium sulphate particles. The numerical results indicate that the presence of $\mathrm{NH}_{3}$ enhances the growth of a freshly formed aerosol.

Equation (4) does not account for molecule size effects on the collision cross section nor the particle thermal speed effects on the relative collisional speeds which may impact the estimation of the growth rates of nanometre-sized particles (Lehtinen and Kulmala, 2003; Nieminen et al., 2010). We performed sensitivity calculations where Eqs. (4-6) were modified, as proposed by Lehtinen and Kulmala (2003), to address these issues. The enhancement of the calculated growth rates was $\sim 5 \%$, which improved the agreement between modelled and measured values at residence times 45 and $60 \mathrm{~s}$, but also contributes to growth overestimation at residence time $90 \mathrm{~s}$.

Figure 11 depicts the experimental growth rates under wet conditions, at a residence time of $90 \mathrm{~s}$ and at three nucleation temperatures and the atmospheric growth rates, obtained in Heidelberg and Hyytiälä during the Quantification of Aerosol Nucleation in the European Boundary Layer (QUEST) project (Fiedler et al., 2005), data obtained in Atlanta during the Atlanta Aerosol Nucleation and Real-time Characterization Experiment (ANARChE) study (Stolzenburg et al., 2005), data from Beijing during the Campaigns of Air Quality Research in Beijing and Surrounding Regions in 2008 (CAREBeijing-2008) (Yue et al., 2010), data from Mace Head Monitoring Station during the Particle Formation and Fate in the Coastal Environment (PARFORCE) campaign (O'Dowd et al., 2002a) and data from Kent, Ohio (Erupe et al., 2010) are depicted for comparison. The theoretical predictions of the growth of ammonium sulphate particles under wet conditions $(\mathrm{RH}=30 \%)$ are also depicted. The best agreement with our data was found for sulphuric aciddriven growth rates from a study by Stolzenburg et al. (2005), who investigated the growth of particles containing ammonium sulphate, which is consistent with the chemical compositions of particles in our study. Most observed atmospheric growth rates correspond to substantially lower $\mathrm{H}_{2} \mathrm{SO}_{4}$ concentrations, and our results thus show that in most cases sulphuric acid alone cannot explain the growth rates observed in the atmosphere. $\mathrm{H}_{2} \mathrm{SO}_{4}$ is the main condensing vapour responsible for particle growth only in large urban areas, where it can contribute up to $60 \%$ of the growth $\left(\mathrm{H}_{2} \mathrm{SO}_{4}\right.$ accounts for the $60 \%$ of growth observed) (Stolzenburg et al., 2005; Yue et al., 2010). In order to explain the atmospheric growth rates, the condensation of additional chemical species is assumed, mainly organic compounds (Erupe et

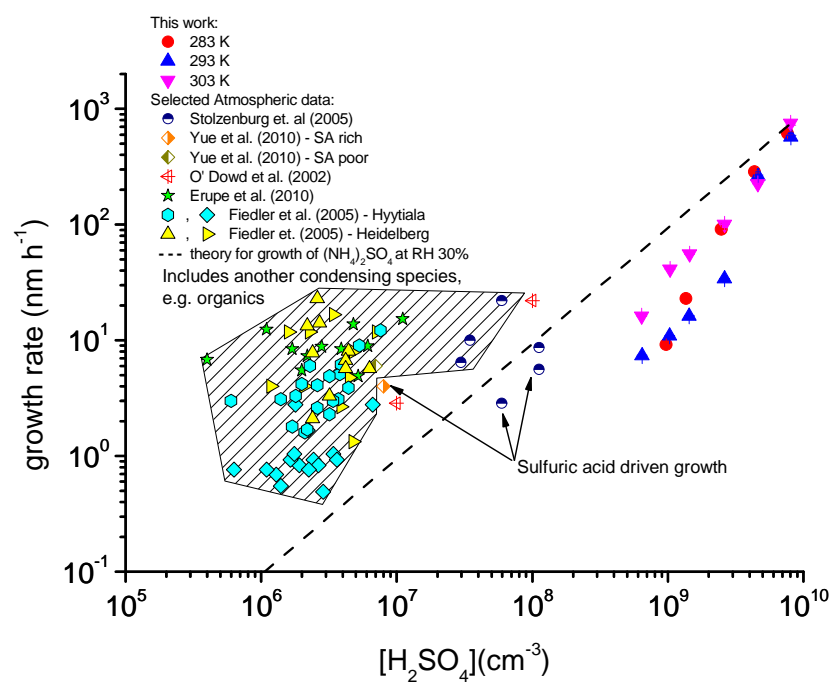

Figure 11. The experimental growth rates obtained under wet conditions $(\mathrm{RH}=30 \%)$, with a residence time of $90 \mathrm{~s}$ and three nucleation temperatures of 283, 293 and $303 \mathrm{~K}$. The atmospheric growth rates, obtained in Heidelberg and Hyytiälä during the QUEST project (Fiedler et al., 2005), data obtained in Atlanta during the ANARChE study (Stolzenburg et al., 2005), data from Beijing during the CAREBeijing-2008 campaign (Yue et al., 2010), data from Mace Head during the PARFORCE campaign (O'Dowd et al., 2002) and data from Kent, Ohio (Erupe et al., 2010) are depicted for comparison. The line presents the theoretical predictions of the growth of ammonium sulphate particles at an RH of $30 \%$.

al., 2010; Fiedler et al., 2010) and iodine species (O'Dowd et al., 2002b).

There are only a few previously reported values of particle growth rates from nucleation experiments. Young et al. (2008) have studied the binary nucleation of $\mathrm{H}_{2} \mathrm{SO}_{4}$ and water at $T=288 \mathrm{~K}$, RH from $11 \%$ to $23 \%$ and at initial $\mathrm{H}_{2} \mathrm{SO}_{4}$ concentrations from $10^{8}$ to $10^{10}$ molecule $\mathrm{cm}^{-3}$. The observed particle growth rates in their experiment ranged from $95 \mathrm{~nm} \mathrm{~h}^{-1}$ to $500 \mathrm{~nm} \mathrm{~h}^{-1}$. Benson et al. (2008) measured the binary nucleation of $\mathrm{H}_{2} \mathrm{SO}_{4}$ and water at $T=288 \mathrm{~K}$, at RH from $10 \%$ to $55 \%$ and at $\mathrm{H}_{2} \mathrm{SO}_{4}$ concentrations from $10^{8}$ to $10^{9}$ molecule $\mathrm{cm}^{-3}$. The particle growth rates estimated from their measurements were roughly from 160 to $490 \mathrm{~nm} \mathrm{~h}^{-1}$. The results of these studies are in good agreement with the growth rates determined from our experiments, as can be seen in Fig. 12.

\section{Conclusions}

The results of an experimental study of sulphuric acid nanoparticle growth under different conditions are presented here. The measurements were performed in a laminar flow tube at temperatures of $283,293 \mathrm{~K}$ and $303 \mathrm{~K}$, at $\mathrm{RH}$ of $1 \%$ and $30 \%$, an initial $\mathrm{H}_{2} \mathrm{SO}_{4}$ concentration from $2 \times 10^{8}$ to $1.4 \times 10^{10}$ molecule $\mathrm{cm}^{-3}$ and at four different residence 


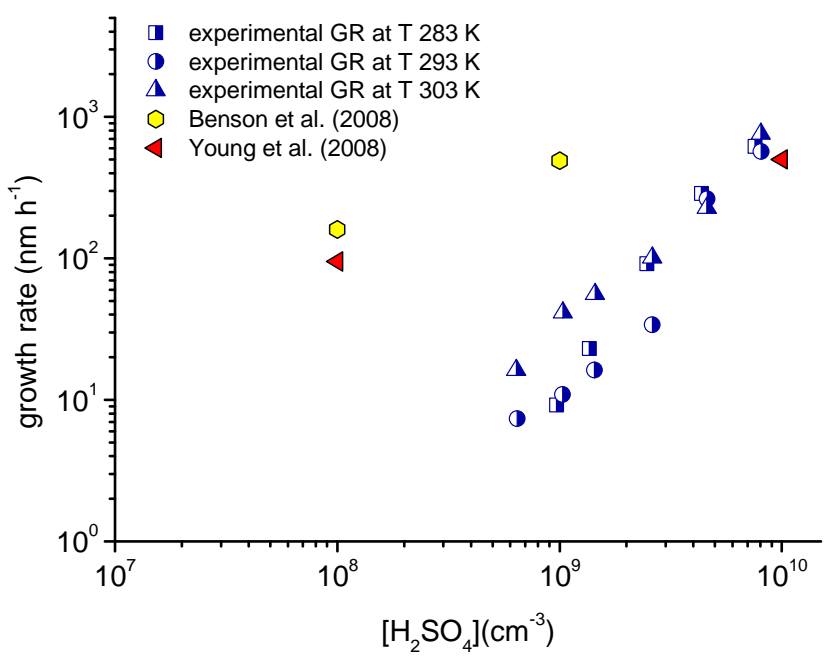

Figure 12. The experimental growth rates determined from measurements conducted at an $\mathrm{RH}$ of $30 \%$, a residence time of $90 \mathrm{~s}$ and three nucleation temperatures are compared with the particle growth rates measured in the nucleation experiments made by Benson et al. (2008) at $T=288 \mathrm{~K}$ and Young et al. (2008) at $T=288 \mathrm{~K}$.

times. The number concentrations and size distributions of the newly formed particles were measured with a UCPC and a DMPS. The obtained size distributions were fitted with a log-normal distribution in order to determine the median particle diameter and the temporal variation of the median diameter was used to calculate the growth rate of the nucleation mode. The variation of the growth rates and their dependence on the experimental conditions were analysed. A comparison of the experimental values with the theoretical ones predicted from a model, considering the growth of particles with three different ammonia-to-sulphate ratios, was made.

It was shown that our system can produce very reproducible results. A strong dependence of the number concentrations of newly formed particles on residence time was observed. The obtained growth rates were found to increase significantly with increasing $\mathrm{H}_{2} \mathrm{SO}_{4}$ concentration. A slightly enhancing effect of increased $\mathrm{RH}$ on growth rates was observed at higher $\mathrm{H}_{2} \mathrm{SO}_{4}$ concentrations, and a clear dependence of the growth rates on increasing nucleation temperature was recorded under dry conditions. The residence time was found to have a negligible effect on the growth rates. The modelled growth rates were highest for ammonium sulphate particles, indicating that $\mathrm{NH}_{3}$ promotes particle growth under both wet and dry conditions. A comparison of our data with atmospheric measurements shows that growth rates based solely on the condensation of $\mathrm{H}_{2} \mathrm{SO}_{4}$ significantly underestimate the growth rates observed in the atmosphere. A satisfactory agreement of our data with the growth rates determined from previous laboratory experimental studies was found.

The wall losses of $\mathrm{H}_{2} \mathrm{SO}_{4}$ derived from experimental growth rates were found to be substantially lower than the diffusion limited values calculated according to Hanson and Eisele (2000). Our results indicate that the wall losses of $\mathrm{H}_{2} \mathrm{SO}_{4}$ are not as great as is commonly presumed. Due to long-lasting experiments, the measurements are believed to be performed under close to wall-equilibrium conditions. We therefore speculate that the wall of the flow tube is not an infinite sink for $\mathrm{H}_{2} \mathrm{SO}_{4}$ molecules, but that there is also a flux of $\mathrm{H}_{2} \mathrm{SO}_{4}$ from the wall into the tube, which is more profound under dry conditions. The correct determination of the sulphuric acid concentration in nucleation measurements is a crucial factor for subsequent analysis and data interpretation. Our results show that neglecting the flux of $\mathrm{H}_{2} \mathrm{SO}_{4}$ from the wall may cause a significant underestimation of the residual $\mathrm{H}_{2} \mathrm{SO}_{4}$ concentration. More detailed measurements are needed to gain a better understanding of the processes influencing the $\mathrm{H}_{2} \mathrm{SO}_{4}$ concentration in experimental devices and the role of sulphuric acid in the early stages of particle growth.

Acknowledgements. The financial support by the Grant Agency of the Academy of Sciences of the Czech Republic (Grant no. IAA200760905) and by Academy of Finland Center of Excellence Program (Project no. 1118615) is gratefully acknowledged.

Edited by: M. Kulmala

\section{References}

Andreae, M. O. and Rosenfeld, D.: Aerosol-cloud-precipitation interactions. Part 1. The nature and sources of cloud-active aerosols, Earth Sci. Rev., 89, 13-41, 2008.

Ayers, G. P., Gillett, R. W., and Gras, J. L.: On the vapor pressure of sulfuric acid, Geophys. Res. Lett., 7, 433-436, 1980.

Ball, S. M., Hanson, D. R., and Eisele, F. L.: Laboratory studies of particle nucleation: Initial results for $\mathrm{H}_{2} \mathrm{SO}_{4}, \mathrm{H}_{2} \mathrm{O}$, and $\mathrm{NH}_{3}$ vapors, J. Geophys. Res., 104, =23709-23718, doi:10.1029/1999JD900411, 1999.

Benson, D. R., Young, L. H., Kameel, F. R., and Lee, S. H.: Laboratory-measured nucleation rates of sulfuric acid and water binary homogenous nucleation from $\mathrm{SO}_{2}+\mathrm{OH}$ reaction, Geophys. Res. Lett., 35, L11801, doi:10.1029/2008GL033387, 2008.

Benson, D. R., Erupe, M. E., and Lee, S.-H.: Laboratorymeasured $\mathrm{H}_{2} \mathrm{SO}_{4}-\mathrm{H}_{2} \mathrm{O}-\mathrm{NH}_{3}$ ternary homogeneous nucleation rates: Initial observations, Geophys. Res. Lett., 36, L15818, doi:10.1029/2009GL038728, 2009.

Benson, D. R., Yu, J. H., Markovich, A., and Lee, S.-H.: Ternary homogeneous nucleation of $\mathrm{H}_{2} \mathrm{SO}_{4}, \mathrm{NH}_{3}$, and $\mathrm{H}_{2} \mathrm{O}$ under conditions relevant to the lower troposphere, Atmos. Chem. Phys., 11, 4755-4766, doi:10.5194/acp-11-4755-2011, 2011.

Berndt, T., Stratmann, F., Sipilä, M., Vanhanen, J., Petäjä, T., Mikkilä, J., Grüner, A., Spindler, G., Lee Mauldin III, R., Curtius, J., Kulmala, M., and Heintzenberg, J.: Laboratory study on new particle formation from the reaction $\mathrm{OH}+\mathrm{SO}_{2}$ : influence of experimental conditions, $\mathrm{H}_{2} \mathrm{O}$ vapour, $\mathrm{NH}_{3}$ and the amine tert-butylamine on the overall process, Atmos. Chem. Phys., 10, 7101-7116, doi:10.5194/acp-10-7101-2010, 2010. 
Biskos, G., Buseck, P. R., and Martin, S. T.: Hygroscopic growth of nucleation-mode acidic sulfate particles, Aerosol. Sci., 40, 338347, 2009.

Brus, D., Hyvärinen, A.-P., Viisanen, Y., Kulmala, M., and Lihavainen, H.: Homogeneous nucleation of sulfuric acid and water mixture: experimental setup and first results, Atmos. Chem. Phys., 10, 2631-2641, doi:10.5194/acp-10-2631-2010, 2010.

Brus, D., Neitola, K., Hyvärinen, A.-P., Petäjä, T., Vanhanen, J., Sipilä, M., Paasonen, P., Kulmala, M., and Lihavainen, H.: Homogenous nucleation of sulfuric acid and water at close to atmospherically relevant conditions, Atmos. Chem. Phys., 11, 52775287, doi:10.5194/acp-11-5277-2011, 2011a.

Brus, D., Neitola, K., Petäjä, T., and Lihavainen, H.: Diffusion coefficient measurements of sulphuric acid in air, Abstract 456, European Aerosol Conference, Manchester, UK, 4.-9.9, 2011 b.

Charlson, R. J., Schwartz, S. E., Hales, J. M., Cess, R. D., Coakley, J. A., Hansen, J. E., and Hofmann, D. J.: Climate forcing by anthropogenic aerosols, Science, 255, 423-430, 1992.

Dal Maso, M., Kulmala, M., Riipinen, I., Wagner, R., Hussein, T., Aalto, P. P., and Lehtinen, K. E. J.: Formation and growth of fresh atmospheric aerosol: eight years of aerosol size distribution data from SMEAR II, Hyytiälä, Finland, Boreal Environ. Res., 10, 323-336, 2005.

Dusek, U., Frank, G. P., Hildebrandt, L., Curtius, J., Schneider, J., Walter, S., Chand, D., Drewnick, F., Hings, S., Jung, D., Borrmann, S., and Andreae, M. O.: Size matters more than chemistry for cloud-nucleating ability of aerosol particles, Science, 312, 1375-1378, 2006.

Erupe, M. E., Benson, D. R., Jingmin, L., Young, L. H., Verheggen, B., Al-Refai, M., Tahboub, O., Cunningham, V., Frimpong, F., Viggiano, A. A., and Lee, S. H.: Correlation of aerosol nucleation rate with sulfuric acid and ammonia in Kent, Ohio: An atmospheric observation, J. Geophys. Res., 115, D23216, doi:10.1029/2010JD013942, 2010.

Fiedler, V., Dal Maso, M., Boy, M., Aufmhoff, H., Hoffmann, J., Schuck, T., Birmili, W., Hanke, M., Uecker, J., Arnold, F., and Kulmala, M.: The contribution of sulphuric acid to atmospheric particle formation and growth: a comparison between boundary layers in Northern and Central Europe, Atmos. Chem. Phys., 5, 1773-1785, doi:10.5194/acp-5-1773-2005, 2005.

Fuchs, N. A. and Sutugin, A. G.: Highly Dispersed Aerosols, Butteworth-Heinemann, Newton Mass., 1970.

Ge, X., Wexler, A. S., and Clegg, S. L.: Atmospheric amines - Part I. A review, Atmos. Environ., 45, 524-546, doi:10.1016/j.atmosenv.2010.10.012, 2011.

Hanson, D. R.: Mass Accommodation of $\mathrm{H}_{2} \mathrm{SO}_{4}$ and $\mathrm{CH}_{3} \mathrm{SO}_{3} \mathrm{H}$ on Water-Sulfuric Acid Solutions from $6 \%$ to $97 \%$ RH, J. Phys. Chem. A, 109, 6919-6927, 2005.

Hanson, D. R. and Eisele, F.: Diffusion of $\mathrm{H}_{2} \mathrm{SO}_{4}$ in Humidified Nitrogen: Hydrated $\mathrm{H}_{2} \mathrm{SO}_{4}$, J. Phys. Chem. A, 104, 1715-1719, 2000.

Herrmann, E., Brus, D., Hyvärinen, A.-P., Stratmann, F., Wilck, M., Lihavainen, H., and Kulmala, M.: A computational fluid dynamics approach to nucleation in the water-sulfuric acid-system, J. Phys. Chem. A, 114, 8033-8042, 2010.

Hirsikko, A., Laakso, L., Horrak, U., Aalto. P., Kerminen, V.-M., and Kulmala, M.: Annual and size dependent variation of growth rates and ion concentrations in boreal forest, Boreal Environ. Res., 10, 357-369, 2005.
Hirsikko, A., Nieminen, T., Gagné, S., Lehtipalo, K., Manninen, H. E., Ehn, M., Hõrrak, U., Kerminen, V.-M., Laakso, L., McMurry, P. H., Mirme, A., Mirme, S., Petäjä, T., Tammet, H., Vakkari, V., Vana, M., and Kulmala, M.: Atmospheric ions and nucleation: a review of observations, Atmos. Chem. Phys., 11, 767798, doi:10.5194/acp-11-767-2011, 2011.

Hyvärinen, A.-P., Raatikainen, T., Laaksonen, A., Viisanen, Y., and Lihavainen, H.: Surface tensions and densities of $\mathrm{H}_{2} \mathrm{SO}_{4}+\mathrm{NH}_{3}+$ water solutions, Geophys. Res. Lett., 32, L16806, doi:10.1021/je034225b, 2005.

Kerminen, V.-M., Petäjä, T., Manninen, H. E., Paasonen, P., Nieminen, T., Sipilä, M., Junninen, H., Ehn, M., Gagné, S., Laakso, L., Riipinen, I., Vehkamäki, H., Kurten, T., Ortega, I. K., Dal Maso, M., Brus, D., Hyvärinen, A., Lihavainen, H., Leppä, J., Lehtinen, K. E. J., Mirme, A., Mirme, S., Hõrrak, U., Berndt, T., Stratmann, F., Birmili, W., Wiedensohler, A., Metzger, A., Dommen, J., Baltensperger, U., Kiendler-Scharr, A., Mentel, T. F., Wildt, J., Winkler, P. M., Wagner, P. E., Petzold, A., Minikin, A., Plass-Dülmer, C., Pöschl, U., Laaksonen, A., and Kulmala, M.: Atmospheric nucleation: highlights of the EUCAARI project and future directions, Atmos. Chem. Phys., 10, 10829-10848, doi:10.5194/acp-10-10829-2010, 2010.

Kirkby, J., Curtius, J., Almeida, J., Dunne, E., Duplissy, J., Ehrhart, S., Franchin, A., Gagné, S., Ickes, L., Kürten, A., Kupc, A., Metzger, A., Riccobono, F., Rondo, L., Schobesberger, S., Tsagkogeorgas, G., Wimmer, D., Amorim, A., Bianchi, F., Breitenlechner, M., David, A., Dommen, J., Downard, A., Ehn, M., Flagan, R., Haider, S., Hansel, A., Hauser, D., Jud, W., Junninen, H., Kreissl, F., Kvashin, A., Laaksonen, A., Lehtipalo, K., Lima, J., Lovejoy, E., Makhmutov, V., Mathot, S., Mikkilä, J., Minginette, P., Mogo, S., Nieminen, T., Onnela, A., Pereira, P., Petäjä, T., Schnitzhofer, R., Seinfeld, J., Sipilä, M., Stozhkov, Y., Stratmann, F., Tomé, A., Vanhanen, J., Viisanen, Y., Aron Vrtala, A., Wagner, P., Walther, H., Weingartner, E., Wex, H., Winkler, P., Carslaw, K., Worsnop, D.,Baltensperger, U., and Kulmala, M.: Role of sulphuric acid, ammonia and galactic cosmic rays in atmospheric aerosol nucleation, Nature, 476, 429-433, doi:10.1038/nature10343, 2011.

Korhonen, P., Kulmala, M., Laaksonen, A., Viisanen, Y., McGraw, R., and Seinfeld, J. H.: Ternary nucleation of $\mathrm{H}_{2} \mathrm{SO}_{4}, \mathrm{NH}_{3}$ and $\mathrm{H}_{2} \mathrm{O}$ in the atmosphere, J. Geophys. Res., 104, 26349-26353, doi:10.1029/1999JD900784, 1999.

Kuang, C., Chen, M., Zhao, J., Smith, J., McMurry, P. H., and Wang, J.: Size and time-resolved growth rate measurements of 1 to 5 $\mathrm{nm}$ freshly formed atmospheric nuclei, Atmos. Chem. Phys., 12, 3573-3589, doi:10.5194/acp-12-3573-2012, 2012.

Kulmala, M.: How particles nucleate and grow, Science, 302, 1000 1001, 2003.

Kulmala, M. and Laaksonen, A.: Binary nucleation of watersulfuric acid system: Comparison of classical theories with different $\mathrm{H}_{2} \mathrm{SO}_{4}$ saturation vapor pressures, J. Chem. Phys., 93, 696-701, 1990.

Kulmala, M. and Kerminen, V. M.: On the formation and growth of atmospheric nanoparticles, Atmos. Res., 90, 132-150, 2008.

Kulmala, M., Pirjola, L., and Mäkelä, J. M.: Stable sulphate clusters as a source of new atmospheric particles, Nature, 404, 66-69, 2000 .

Kulmala, K., Kerminen, V.-M., Antilla, T., Laaksonen, A., and O'Dowd, C. D.: Organic aerosol formation via su- 
plhate cluster activation, J. Geophys. Res., 109, D04205, doi:10.1029/2003JD003961, 2004a.

Kulmala, M., Vehkamäki, H., Petäjä, T., Dal Maso, M., Lauri, A., Kerminen, V.-M., Birmili, W., And McMurry, P. H.: Formation and growth rates of ultrafine atmospheric particles: a review of observations, J. Aerosol Sci., 35, 143-176, 2004b.

Lee, S.-H., Reeves, J. M., Wilson, J. C., Hunton, D. E., Viggiano, A. A., Miller, T. M., Ballenthin, J. O., and Lait, L. R.: Particle Formation by Ion Nucleation in the Upper Troposphere and Lower Stratosphere, Science, 301, 1886-1889, 2003.

Lehtinen, K. E. J. and Kulmala, M.: A model for particle formation and growth in the atmosphere with molecular resolution in size, Atmos. Chem. Phys., 3, 251-257, doi:10.5194/acp-3-251-2003, 2003.

Leppä, J., Anttila, T., Kerminen, V.-M., Kulmala, M., and Lehtinen, K. E. J.: Atmospheric new particle formation: real and apparent growth of neutral and charged particles, Atmos. Chem. Phys., 11, 4939-4955, doi:10.5194/acp-11-4939-2011, 2011.

Lovejoy, E. R., Curtius, J., and Froyd, K. D.: Atmospheric ioninduced nucleation of sulphuric acid and water, J. Geophys. Res., 109, D08204, doi:10.1029/2003JD004460, 2004.

Mäkela, J. M., Yli-Koivisto, S., Hiltunen, V., Seidl, W., Swietlicki, E., Teinilä, K., Sillanpää, M., Koponen, I. K., Paatero, J., Rosman, K., and hämeri, K.: Chemical composition of aerosol during particle formation events in boreal forest, Tellus B, 53, 380-393, 2001.

Merikanto, J., Napari, I., Vehkamäki, H., Anttila, T., and Kulmala, M.: New parameterization of sulfuric acid-ammonia-water ternary nucleation rates at tropospheric conditions, J. Geophys. Res., 112, D15207, doi:10.1029/2006JD007977, 2007.

Merikanto, J., Spracklen, D. V., Mann, G. W., Pickering, S. J., and Carslaw, K. S.: Impact of nucleation on global CCN, Atmos. Chem. Phys., 9, 8601-8616, doi:10.5194/acp-9-8601-2009, 2009.

Neitola, K., Brus, D., Makkonen, U., Sipilä, M., Mauldin III, R. L., Kyllönen, K., Lihavainen, H., and Kulmala, M.: Total sulphate vs. sulphuric acid monomer in nucleation studies: which represents the "true" concentration?, Atmos. Chem. Phys. Discuss., 13, 2313-2350, doi:10.5194/acpd-13-2313-2013, 2013.

Nieminen, T., Lehtinen, K. E. J., and Kulmala, M.: Sub-10 nm particle growth by vapor condensation - effects of vapor molecule size and particle thermal speed, Atmos. Chem. Phys., 10, 9773 9779, doi:10.5194/acp-10-9773-2010, 2010.

O'Dowd, C., Aalto, P., Hämeri, K., Kulmala, M., and Hoffmann, T.: Atmospheric particles from organic vapours, Nature, 416, 497498, 2002a.

O’Dowd, C. D., Jimenez, J. L., Bahreini, R., Flagan, R. C., Seinfeld, J. H., Hämeri, K., Pirjola, L., Kulmala, M., Jennings, S. G., and Hoffmann, T.: Marine aerosol formation from biogenic iodine emissions, Nature, 417, 632-636, 2002 b.

Qiu, Ch. and Zhang, R.: Physiochemical Properties of Alkylaminium Sulfates: Hygroscopicity, Thermostability, and Density, Environ. Sci. Technol., 46, 4474-4480, 2012.

Seinfeld, J. H. and Pandis, S. N.: Atmospheric Chemistry and Physics: From Air Pollution to Climate Change, John Wiley, New York, 1998.

Sihto, S.-L., Kulmala, M., Kerminen, V.-M., Dal Maso, M., Petäjä, T., Riipinen, I., Korhonen, H., Arnold, F., Janson, R., Boy, M., Laaksonen, A., and Lehtinen, K. E. J.: Atmospheric sulphuric acid and aerosol formation: implications from atmospheric measurements for nucleation and early growth mechanisms, Atmos. Chem. Phys., 6, 4079-4091, doi:10.5194/acp-6-4079-2006, 2006.

Sipilä, M., Berndt, T., Petäjä, T., Brus, D., Vanhanen, J., Stratmann, F., Patokoski, J., Mauldin III, R. L., Hyvärinen, A.-P., Lihavainen, H., and Kulmala, M.: The role of sulfuric acid in atmospheric nucleation, Science, 327, 1243-1246, 2010.

Smith, J. N., Dunn, M. J., VanReken, T. M., Iida, K., Stolzenburg, M. R., McMurry, P. H., and Huey, P. H., Chemical composition of atmospheric nanoparticles formed from nucleation in Tecamac, Mexico: evidence for an important role for organic species in nanoparticle growth, Geophys. Res. Lett., 35, L04808, doi:10.1029/2007GL032523, 2008.

Spracklen, D. V., Carslaw, K. S., Kulmala, M., Kerminen, V.-M., Mann, G. W., and Sihto, S.-L.: The contribution of boundary layer nucleation events to total particle concentrations on regional and global scales, Atmos. Chem. Phys., 6, 5631-5648, doi:10.5194/acp-6-5631-2006, 2006.

Spracklen, D. V., Carslaw, K. S., Kulmala, M., Kerminen, V. M., Sihto, S.-L., Riipinen, I., Merikanto, J., Mann, G. W., Chipperfield, M. P., Wiedensohler, A., Birmili, W., and Lihavainen, H.: Contribution of particle formation to global cloud condensation nuclei concentrations, Geophys. Res. Lett., 35, L06808, doi:10.1029/2007G1033038, 2008.

Staples, B. R.: Activity and Osmotic Coefficients of Aqueous Sulfuric Acid at 298.15 K, J. Phys. Chem. Ref. Data, 10, 779-798, 1981.

Stolzenburg, M. R., McMurry, P. H., Sakurai, H., Smith, J. N., Mauldin III, R. L., Eisele, F. L., and Clement, Ch. F.: Growth rates of freshly nucleated atmospheric particles in Atlanta, J. Geophys. Res., 110, D22S05, doi:10.1029/2005JD005935, 2005.

Tang, I. N. and Munkelwitz, H. R.: Water activities, densities, and refractive indices of aqueous sulfates and sodium nitrate droplets of atmospheric importance, J. Geophys. Res., 99, 18801-18808, 1994.

ten Brink, H., Otjes, R., Jongejan, P., and Slanina, S.: An instrument for semi-continuous monitoring of the size-distribution of nitrate, ammonium, sulphate and chloride in aerosol, Atmos. Environ., 41, 2768-2779, 2007.

Vehkamäki, H., Kulmala, M., Napari, I., Lehtinen, K. E. J., Timmreck, C., Noppel, M., and Laaksonen, A.: An improved parameterization for sulfuric acid-water nucleation rates for tropospheric and stratospheric conditions, J. Geophys. Res., 107, 4622, doi:10.1029/2002JD002184, 2002.

Viisanen, Y., Kulmala, M., and Laaksonen, A.: Experiments on gasliquid nucleation of sulfuric acid and water, J. Chem. Phys., 107, 920-926, 1997.

Weber, R. J., Marti, J. J., McMurry, P. H., Eisele, F. L., Tanner, D. J., and Jefferson, A.: measurements of new particle formation and ultrafine particle growth rates at a clean continental site, J. Geophys. Res., 102, 4373-4385, 1997.

Wiedensohler, A. and Fissan, H. J.: Bipolar Charge Distributions of Aerosol Particles in High-Purity Argon and Nitrogen, Aerosol Sci. Tech., 14, 358-364, doi:10.1080/02786829108959498, 1991.

Wiedensohler, A., Birmili, W., Nowak, A., Sonntag, A., Weinhold, K., Merkel, M., Wehner, B., Tuch, T., Pfeifer, S., Fiebig, M., Fjäraa, A. M., Asmi, E., Sellegri, K., Depuy, R., Venzac, H., Vil- 
lani, P., Laj, P., Aalto, P., Ogren, J. A., Swietlicki, E., Williams, P., Roldin, P., Quincey, P., Hüglin, C., Fierz-Schmidhauser, R., Gysel, M., Weingartner, E., Riccobono, F., Santos, S., Grüning, C., Faloon, K., Beddows, D., Harrison, R., Monahan, C., Jennings, S. G., O’Dowd, C. D., Marinoni, A., Horn, H.-G., Keck, L., Jiang, J., Scheckman, J., McMurry, P. H., Deng, Z., Zhao, C. S., Moerman, M., Henzing, B., de Leeuw, G., Löschau, G., and Bastian, S.: Mobility particle size spectrometers: harmonization of technical standards and data structure to facilitate high quality long-term observations of atmospheric particle number size distributions, Atmos. Meas. Tech., 5, 657-685, doi:10.5194/amt5-657-2012, 2012.

Wyslouzil, B. E., Seinfeld, J. H., Flagan, R. C., and Okuyama, K.: Binary nucleation in acid-water systems II: Sulfuric acid-water and a comparison with methanesulfonic acid-water, J. Chem. Phys., 94, 6842-6850, 1991.

Young, L. H., Benson, D. R., Kameel, F. R., Pierce, J. R., Junninen, H., Kulmala, M., and Lee, S.-H.: Laboratory studies of $\mathrm{H}_{2} \mathrm{SO}_{4} / \mathrm{H}_{2} \mathrm{O}$ binary homogeneous nucleation from the $\mathrm{SO}_{2}+\mathrm{OH}$ reaction: evaluation of the experimental setup and preliminary results, Atmos. Chem. Phys., 8, 4997-5016, doi:10.5194/acp-8-4997-2008, 2008.
Yu, F.: Ion-mediated nucleation in the atmosphere: Key controlling parameters, implications, and look-up table, J. Geophys. Res., 115, D03206, doi:10.1029/2009JD012630, 2010.

Yue, D. L., Hu, M., Zhang, R. Y., Wang, Z. B., Zheng, J., Wu, Z. J., Wiedensohler, A., He, L. Y., Huang, X. F., and Zhu, T.: The roles of sulfuric acid in new particle formation and growth in the mega-city of Beijing, Atmos. Chem. Phys., 10, 4953-4960, doi:10.5194/acp-10-4953-2010, 2010.

Zhang, R., Suh, I., Zhao, J., Zhang, D., Fortner, E. C., Tie, X., Molina, L. T., and Molina M. J.: Atmospheric new particle formation enhanced by organic acids, Science, 304, 1487-1490, 2004.

Zhang, R., Khalizov, A., Wang, L., Hu, M., and Xu, W.: Nucleation and growth of nanoparticles in the atmosphere, Chem. Rev., 112, 1957-2011, doi:10.1021/cr2001756, 2012. 